\title{
LEVEL II SCOUR ANALYSIS FOR BRIDGE 20 (BURKTH00560020) on TOWN HIGHWAY 56, crossing the EAST BRANCH PASSUMPSIC RIVER, BURKE, VERMONT
}

Open-File Report 98-555

Prepared in cooperation with

VERMONT AGENCY OF TRANSPORTATION

and

FEDERAL HIGHWAY ADMINISTRATION

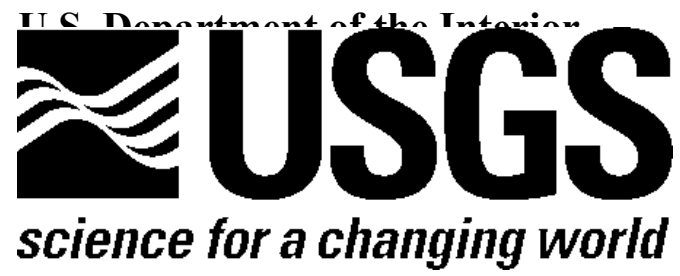




\section{LEVEL II SCOUR ANALYSIS FOR BRIDGE 20 (BURKTH00560020) on TOWN HIGHWAY 56, crossing the EAST BRANCH PASSUMPSIC RIVER, BURKE, VERMONT}

By MICHELLE M. SERRA AND TIMOTHY SEVERANCE

U.S. Geological Survey

Open-File Report 98-555

Prepared in cooperation with

VERMONT AGENCY OF TRANSPORTATION

and

FEDERAL HIGHWAY ADMINISTRATION 


\title{
U.S. DEPARTMENT OF THE INTERIOR BRUCE BABBITT, Secretary
}

\author{
U.S. GEOLOGICAL SURVEY
}

Thomas J. Casadevall, Acting Director

For additional information write to:

District Chief

U.S. Geological Survey 361 Commerce Way

Pembroke, NH 03275-3718
Copies of this report may be purchased from:

U.S. Geological Survey

Branch of Information Services

Open-File Reports Unit

Box 25286

Denver, CO 80225-0286 


\section{CONTENTS}

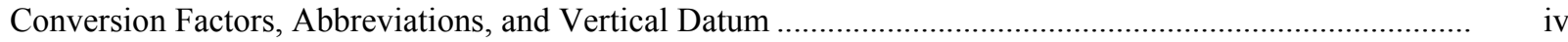

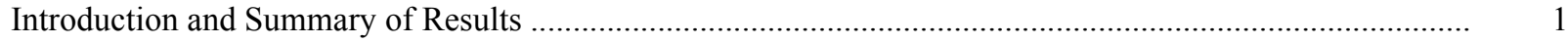

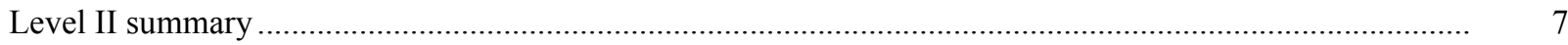

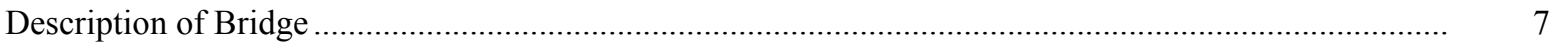

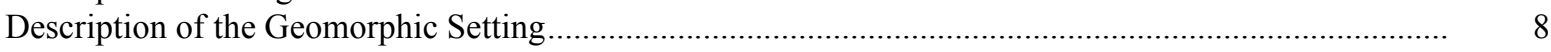

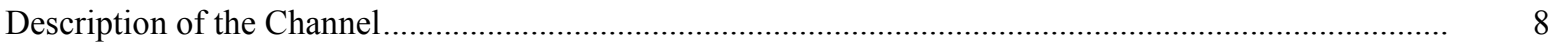

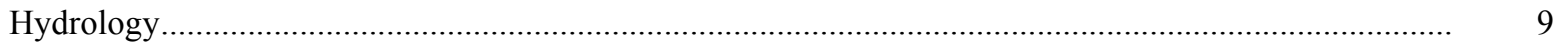

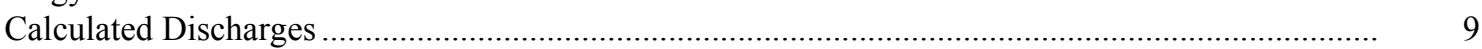

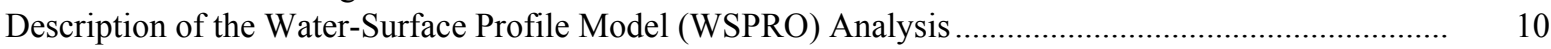

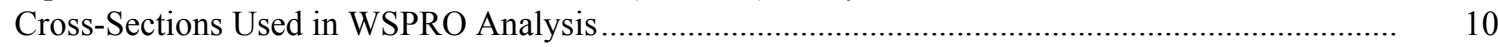

Data and Assumptions Used in WSPRO Model ........................................................................ 11

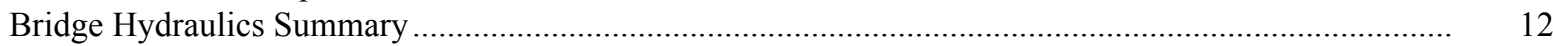

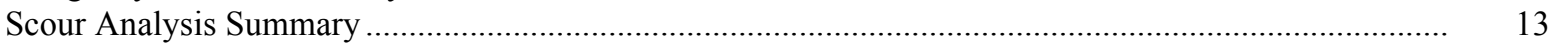

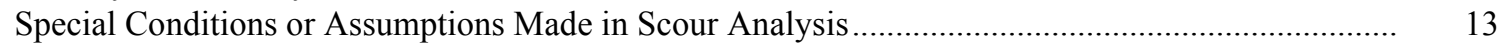

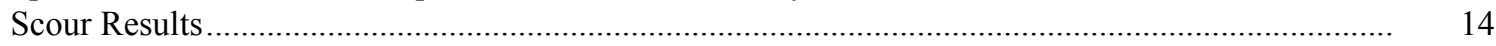

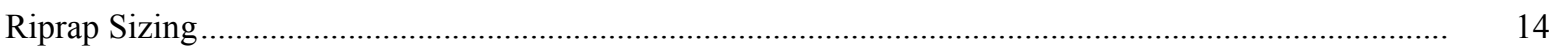

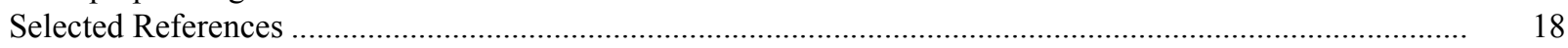

Appendices:

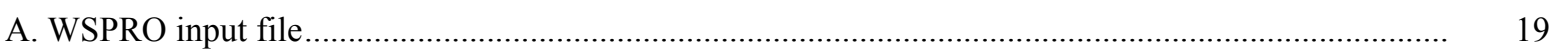

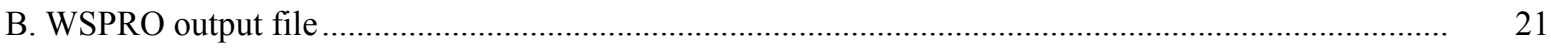

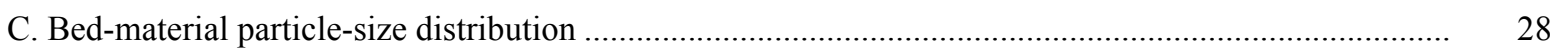

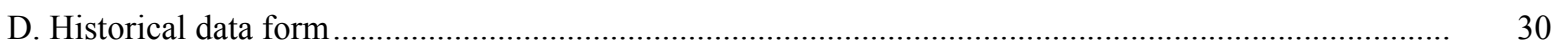

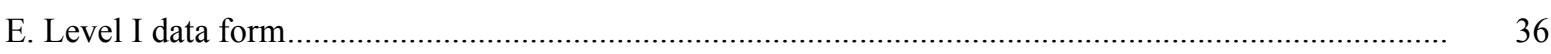

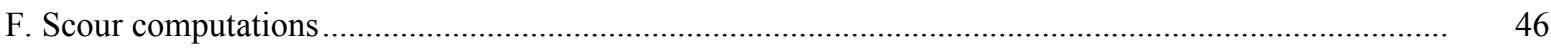

\section{FIGURES}

1. Map showing location of study area on USGS 1:24,000 scale map

2. Map showing location of study area on Vermont Agency of Transportation town highway map

3. Structure BURKTH00560020 viewed from upstream (August 15, 1995) ....

4. Downstream channel viewed from structure BURKTH00560020 (August 15, 1995).............................. 5

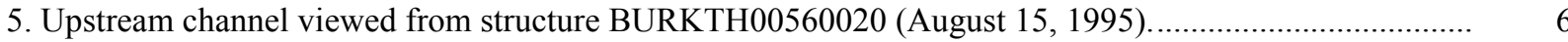

6. Structure BURKTH00560020 viewed from downstream (August 15, 1995).

7. Water-surface profiles for the 100- and 500-year discharges at structure

BURKTH00560020 on Town Highway 56, crossing the East Branch Passumpsic River,

Burke, Vermont.

8. Scour elevations for the 100- and 500-year discharges at structure

BURKTH00560020 on Town Highway 56, crossing the East Branch Passumpsic River,

Burke, Vermont.

\section{TABLES}

1. Remaining footing/pile depth at abutments for the 100-year discharge at structure

BURKTH00560020 on Town Highway 56, crossing the East Branch Passumpsic River,

Burke, Vermont.

2. Remaining footing/pile depth at abutments for the 500-year discharge at structure

BURKTH00560020 on Town Highway 56, crossing the East Branch Passumpsic River,

Burke, Vermont. 


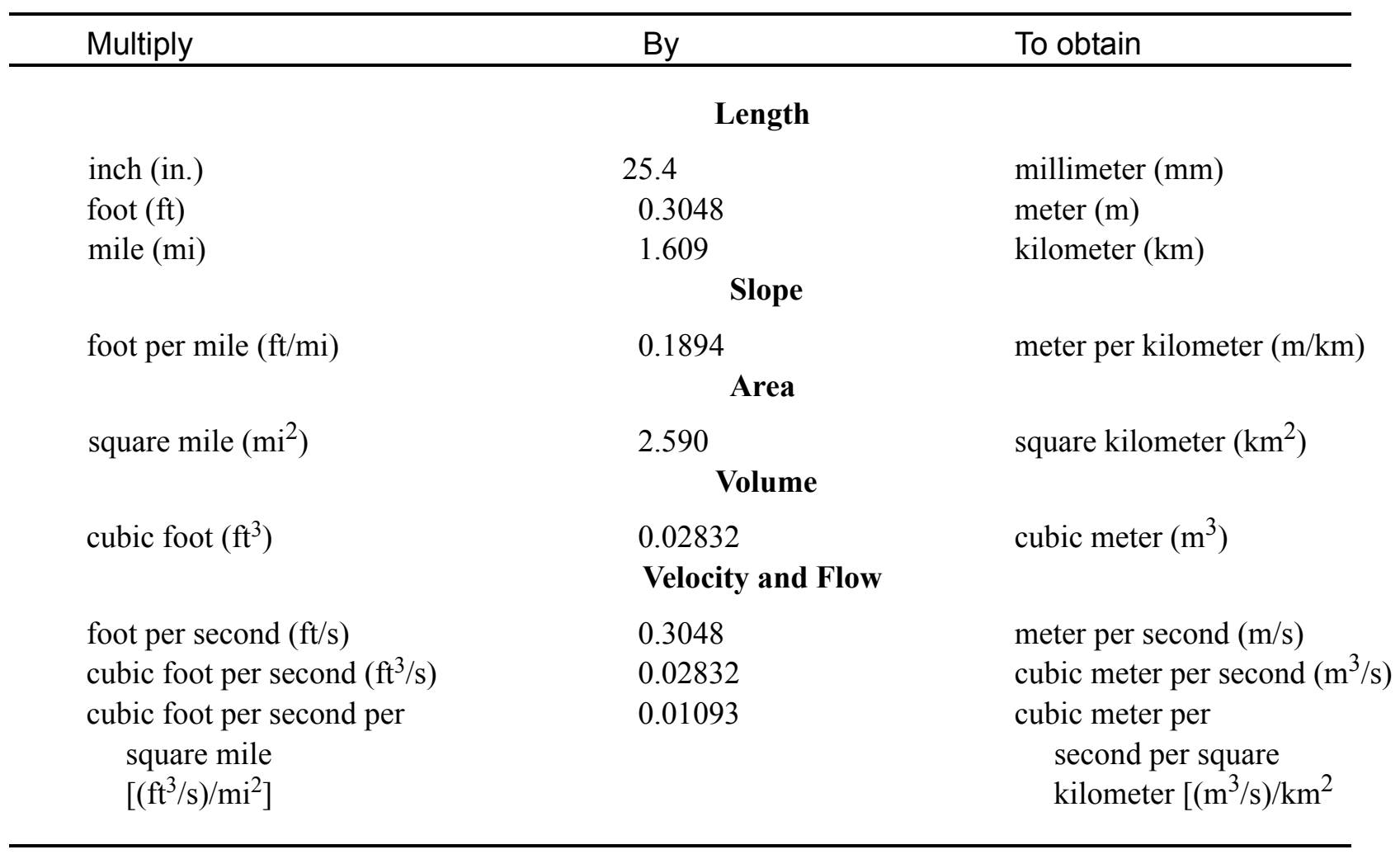

\section{OTHER ABBREVIATIONS}

$\begin{array}{lrlr}\mathrm{BF} & \begin{array}{r}\text { bank full } \\ \mathrm{cfs}\end{array} & \text { LWW } & \text { left wingwall } \\ \mathrm{D}_{50} & \begin{array}{r}\text { cubic feet per second } \\ \text { maximum }\end{array} \\ \mathrm{DS} & \text { Max } & \text { main channel } \\ \mathrm{elev} & \text { downstream } & \text { RAB } & \text { riameter of bed material } \\ \mathrm{f} / \mathrm{p} & \text { elevation } & \text { RABUT } & \text { floce of right abutment } \\ \mathrm{ft}^{2} & \text { flood plain } & \text { RB } & \text { right bank } \\ \mathrm{ft} / \mathrm{ft} & \text { square feet } & \text { ROB } & \text { right overbank } \\ \mathrm{FEMA} & \text { feet per foot } & \text { RWW } & \text { right wingwall } \\ \text { FHWA } & \text { Federal Emergency Management Agency } & \text { TH } & \text { town highway } \\ \text { JCT } & \text { Federal Highway Administration } & \text { UB } & \text { under bridge } \\ \text { LAB } & \text { junction } & \text { US } & \text { upstream } \\ \text { LABUT } & \text { left abutment } & \text { USGS } & \text { United States Geological Survey } \\ \text { LB } & \text { face of left abutment } & \text { VTAOT } & \text { Vermont Agency of Transportation } \\ \text { LOB } & \text { left bank } & \text { WSPRO } & \text { water-surface profile model } \\ & \text { left overbank } & \text { yr } & \text { year }\end{array}$

In this report, the words "right" and "left" refer to directions that would be reported by an observer facing downstream. Sea level: In this report, "sea level" refers to the National Geodetic Vertical Datum of 1929-- a geodetic datum derived from a general adjustment of the first-order level nets of the United States and Canada, formerly called Sea Level Datum of 1929.

In the appendices, the above abbreviations may be combined. For example, USLB would represent upstream left bank. 


\title{
LEVEL II SCOUR ANALYSIS FOR BRIDGE 20 (BURKTH00560020) ON TOWN HIGHWAY 56, CROSSING THE EAST BRANCH PASSUMPSIC RIVER, BURKE, VERMONT
}

\author{
By Michelle M. Serra and Timothy Severance
}

\section{INTRODUCTION AND SUMMARY OF RESULTS}

This report provides the results of a detailed Level II analysis of scour potential at structure BURKTH00560020 on Town Highway 56 crossing the East Branch Passumpsic River, Burke, Vermont (figures 1-8). A Level II study is a basic engineering analysis of the site, including a quantitative analysis of stream stability and scour (FHWA, 1993). Results of a Level I scour investigation also are included in Appendix E of this report. A Level I investigation provides a qualitative geomorphic characterization of the study site. Information on the bridge, gleaned from Vermont Agency of Transportation (VTAOT) files, was compiled prior to conducting Level I and Level II analyses and is found in appendix D.

The site is in the White Mountain section of the New England physiographic province in northeastern Vermont. The $51.0-\mathrm{mi}^{2}$ drainage area is in a predominantly rural and forested basin. In the vicinity of the study site, the surface cover is forested except for the left bank upstream and downstream of the bridge which also has some sections of lawn.

In the study area, the East Branch Passumpsic River has an incised, sinuous channel with a slope of approximately $0.004 \mathrm{ft} / \mathrm{ft}$, an average channel top width of $53 \mathrm{ft}$ and an average bank height of $3 \mathrm{ft}$. The channel bed material ranges from gravel to boulders with a median grain size $\left(\mathrm{D}_{50}\right)$ of $99.6 \mathrm{~mm}(0.327 \mathrm{ft})$. The geomorphic assessment at the time of the Level I and Level II site visit on August 15, 1995, indicated that the reach was stable.

The Town Highway 56 crossing of the East Branch Passumpsic River is a 46-ft-long, onelane bridge consisting of one 44-foot steel-beam span (Vermont Agency of Transportation, written communication, March 24, 1995). The opening length of the structure parallel to the bridge face is $40.8 \mathrm{ft}$. The bridge is supported by vertical, concrete and laid-up stone abutments with wingwalls. The channel is skewed approximately 30 degrees to the opening while the computed opening-skew-to-roadway is 5 degrees. 
During the Level I assessment, a scour hole $1.5 \mathrm{ft}$ deeper than the mean thalweg depth was observed along the right side of the channel upstream. A scour hole $1.0 \mathrm{ft}$ deeper than the mean thalweg depth was observed along the upstream end of the left abutment. A scour hole up to $3 \mathrm{ft}$ deeper than the mean thalweg was observed close to the right bank, extending from under, to downstream of the bridge. Scour protection measures at the site consisted of type-3 stone fill (less than 48 inches diameter) at the upstream and downstream right wingwalls, the right abutment, and the right bank upstream and downstream. Type-2 stone fill (less than 36 inches diameter) had been placed at the upstream and downstream left wingwalls and along the upstream left bank. The downstream right bank has type- 1 stonefill (less than 12 inches diameter), as well as type- 2 and type- 3 stone-fill. Additional details describing conditions at the site are included in the Level II Summary and appendices D and E.

Scour depths and recommended rock rip-rap sizes were computed using the general guidelines described in Hydraulic Engineering Circular 18 (Richardson and Davis, 1995) for the 100- and 500-year discharges. In addition, the incipient roadway-overtopping discharge was determined and analyzed as another potential worst-case scour scenario. Total scour at a highway crossing is comprised of three components: 1) long-term streambed degradation; 2) contraction scour (due to accelerated flow caused by a reduction in flow area at a bridge) and; 3 ) local scour (caused by accelerated flow around piers and abutments). Total scour is the sum of the three components. Equations are available to compute depths for contraction and local scour and a summary of the results of these computations follows.

Contraction scour for all modelled flows was $0 \mathrm{ft}$. Abutment scour ranged from 5.8 to $7.5 \mathrm{ft}$ for the left abutment and from 10.7 to $14.5 \mathrm{ft}$ for the right abutment. The worst-case abutment scour occurred at the 500-year discharge for the right abutment and at the 100year discharge for the left abutment. Additional information on scour depths and depths to armoring are included in the section titled "Scour Results". Scoured-streambed elevations, based on the calculated scour depths, are presented in tables 1 and 2. A cross-section of the scour computed at the bridge is presented in figure 8. Scour depths were calculated assuming an infinite depth of erosive material and a homogeneous particle-size distribution.

It is generally accepted that the Froehlich equation (abutment scour) gives "excessively conservative estimates of scour depths" (Richardson and Davis, 1995, p. 46). Usually, computed scour depths are evaluated in combination with other information including (but not limited to) historical performance during flood events, the geomorphic stability assessment, existing scour protection measures, and the results of the hydraulic analyses. Therefore, scour depths adopted by VTAOT may differ from the computed values documented herein. 


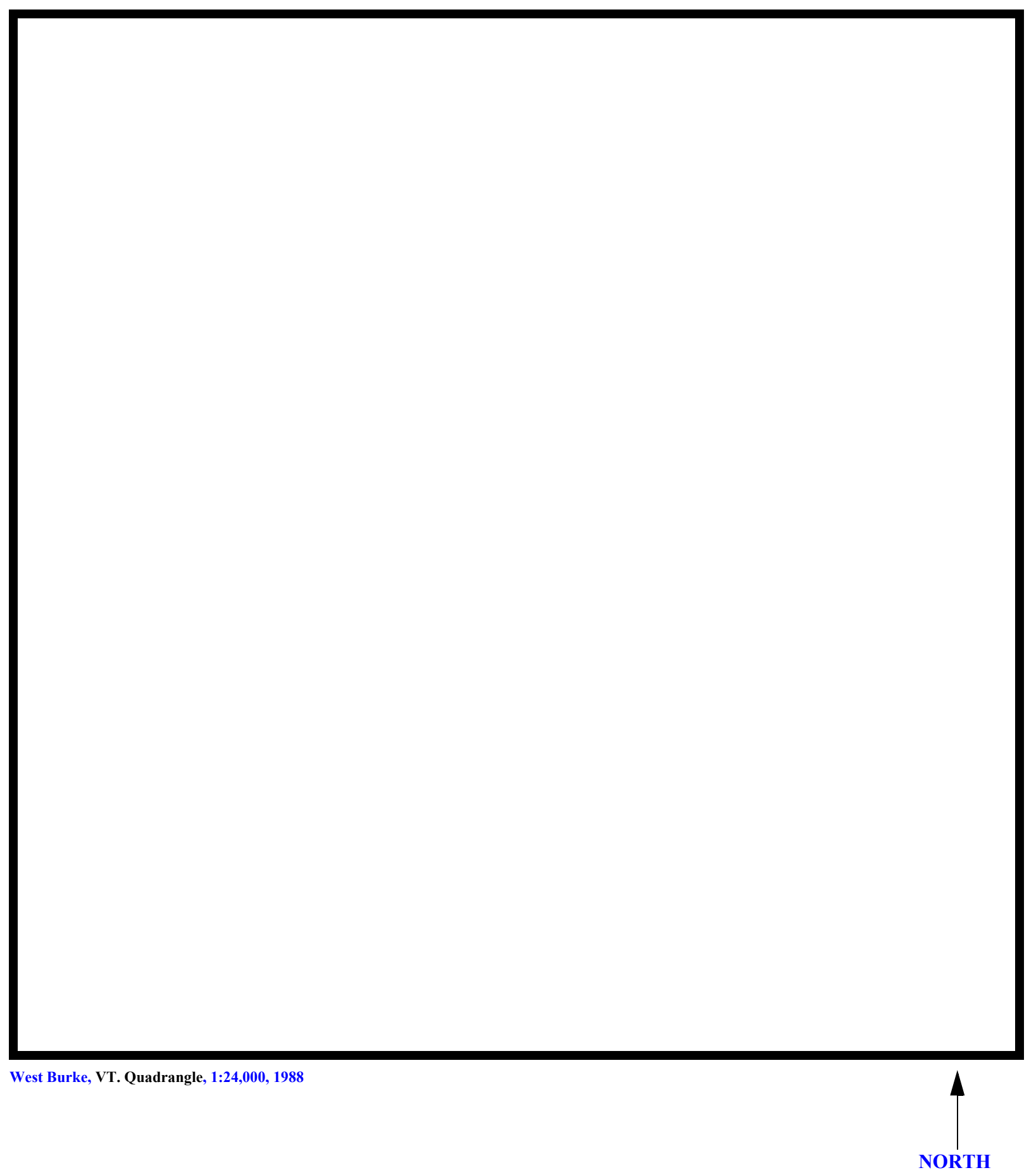

Figure 1. Location of study area on USGS 1:24,000 scale map. 
Figure 2. Location of study area on Vermont Agency of Transportation town highway map. 

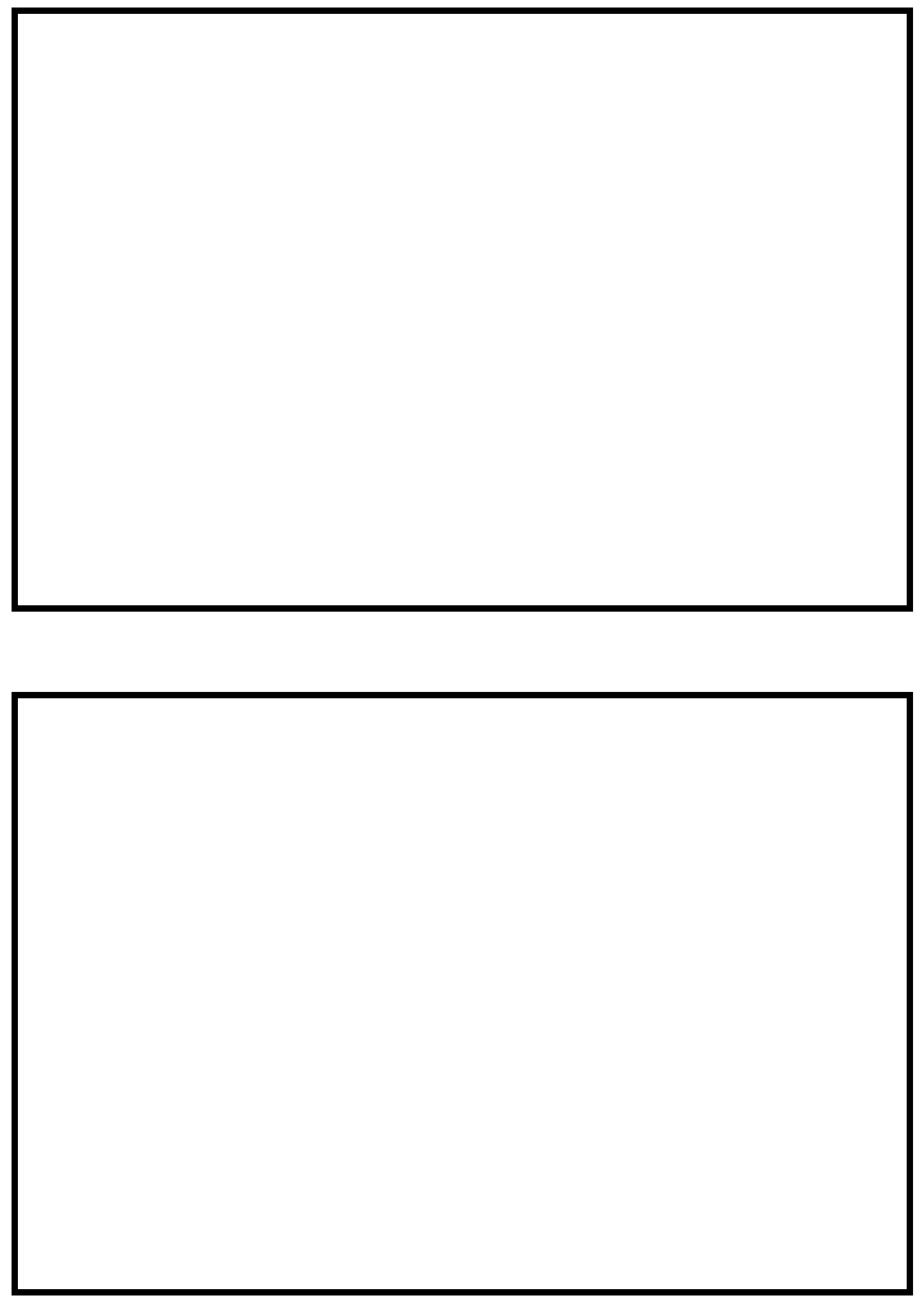




\section{LEVEL II SUMMARY}

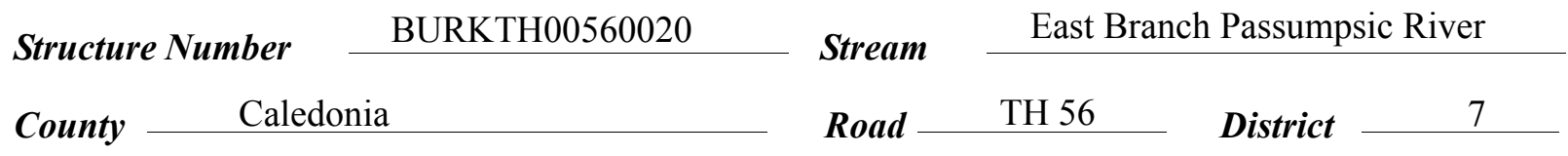

\section{Description of Bridge}

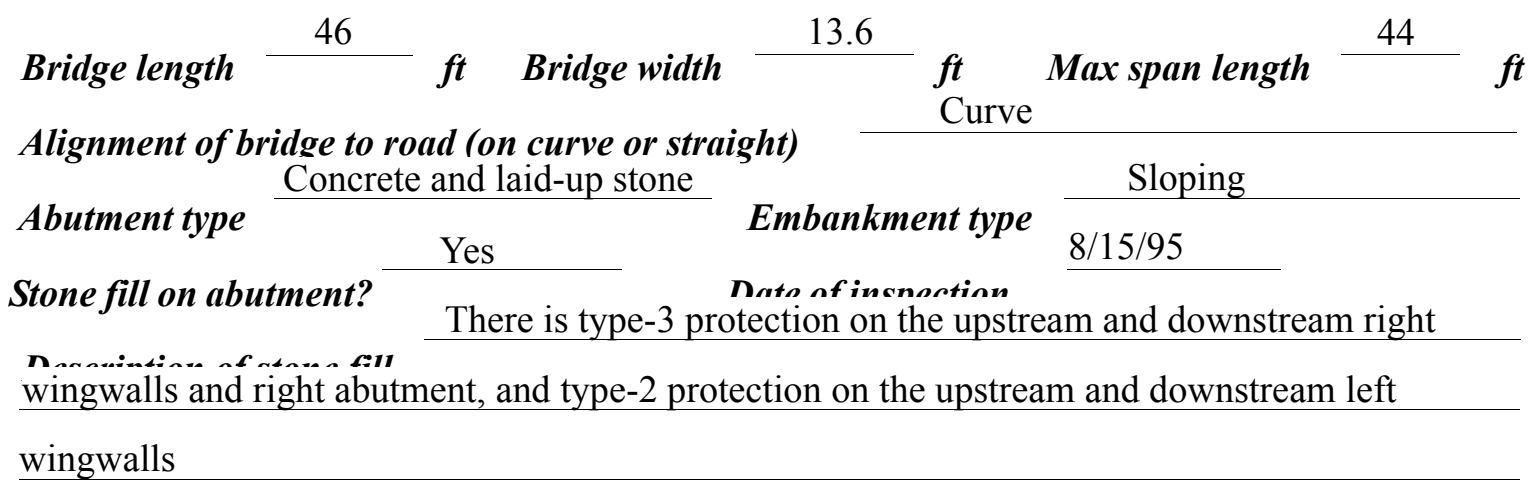

The right abutment and wingwalls are made of

concrete, while the left abutment and wingwalls are stone masonry. There are scour holes at the upstream end of the left abutment and along the channel in front of the Rabut.

Yes $\quad 30$

Is bridge skewed to flood flow according to Yes 'survey? Angle

There is a moderate channel bend in the upstream reach. A scour hole has developed in the

location where the bend impacts the right bank and abutment.

Debris accumulation on bridge at time of Level I or Level II site visit:

\begin{tabular}{|c|c|c|c|}
\hline & $\begin{array}{c}\text { Date of insnortion } \\
8 / 15 / 95 \\
\end{array}$ & $\begin{array}{l}\text { Percent of alommol } \\
\text { blocked hortzontatly }\end{array}$ & $\begin{array}{l}\text { Percent of } 0 \\
\text { blocked verticatty }\end{array}$ \\
\hline & $8 / 15 / 95$ & 0 & 0 \\
\hline
\end{tabular}

Level II

The potential for debris is moderate. There is some debris both upstream and downstream of the bridge.

Potential for debris

None as of 8/15/95.

Dosrriho any, foaturos noar ar at tho hridoo that mav, affort flow, (includo ahsorvation dato) 


\section{Description of the Geomorphic Setting}

General topography The channel is located in a moderate relief valley with narrow flood plains on the left bank and moderate to steeply sloping valley walls on the right bank.

Geomorphic conditions at bridge site: downstream (DS), upstream (US)

Date of inspection $\quad 8 / 15 / 95$

DS left: $\quad$ Moderately sloped channel bank to narrow flood plain

DS right: $\quad$ Steeply sloping channel bank to steep valley wall

US left: $\quad$ Mildly sloping channel bank to narrow flood plain

US right: $\quad$ Moderately sloping channel bank to steep valley wall

\section{Description of the Channel}

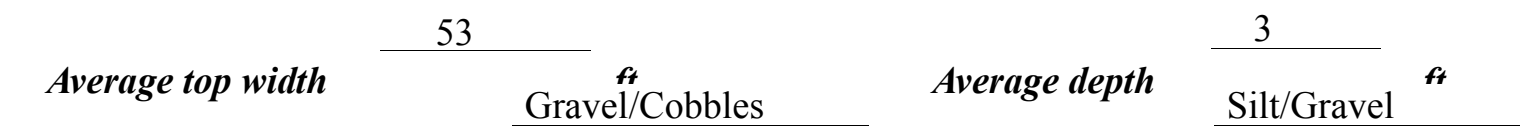

Predominant bed material Bank material Perennial but flashy

and sinuous with semi-alluvial channel boundaries and narrow point bars.

$8 / 15 / 95$

Vegetative co 1 Trees and shrübs

DS left: $\quad$ Trees and some grass

DS right: $\quad$ Trees and brush

US left: $\quad$ Trees and shrubs

US right: $\quad$ Yes

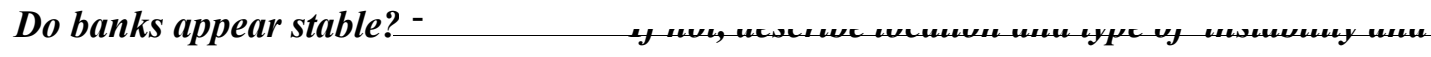

date of observatton.

None as of $8 / 15 / 95$

Describe any obstructions in channel and date of observation. 


\title{
Hydrology
}

Drainage area $\stackrel{51.0}{\mathrm{mi}} \mathbf{i}^{2}$

Percentage of drainage area in physiographic provinces: (approximate)

Physiographic province/section

New England/White Mountain
Percent of drainage area 100

\begin{abstract}
Is drainage area considered rural or urban?
Rural urbanization:

Describe any significant
\end{abstract}

urbanization:

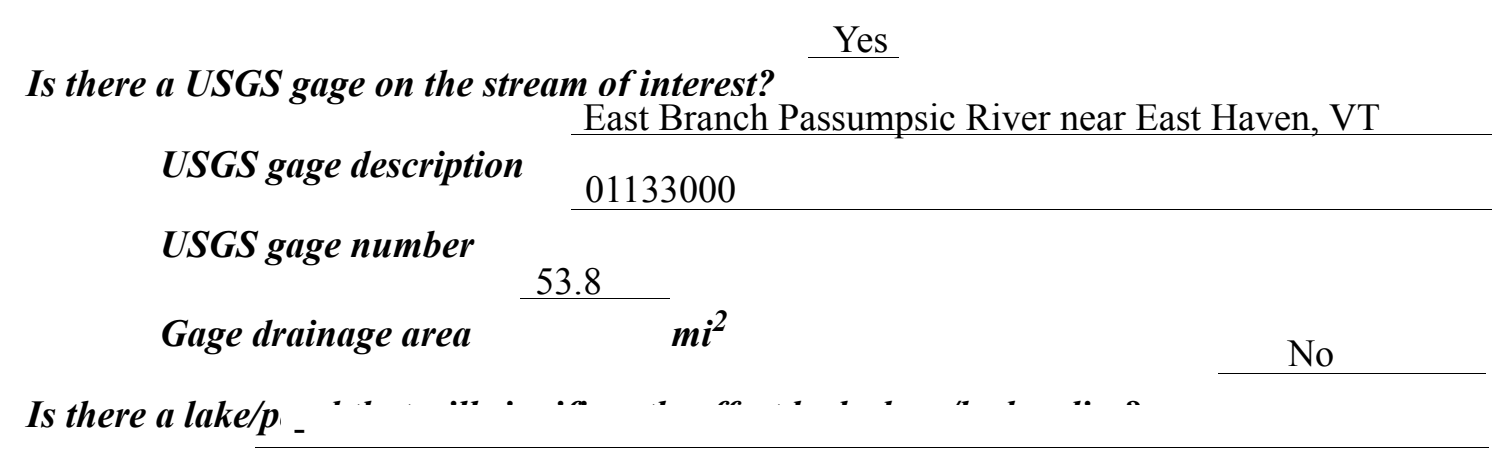

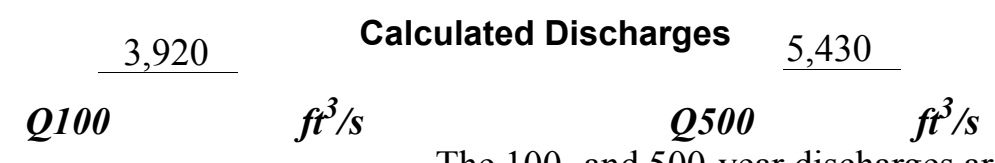

The 100- and 500-year discharges are based on the discharges recorded at the East Haven gage was conducted for the period of record from 1948 1979 in accordance with the guidelines documented by the Interagency Advisory Committee on Water Data (1982). These values were within a range defined by flood frequency curves developed from several empirical methods (Benson, 1962; Johnson and Tasker, 1974; FHWA, 1983; Potter, 1957a\&b; Talbot, 1887). Each curve was extended graphically to the 500 -year event. 


\section{Description of the Water-Surface Profile Model (WSPRO) Analysis}

Datum for WSPRO analysis (USGS survey, sea level, VTAOT plans)

USGS survey

Datum tie between USGS survey and VTAOT plans

None

Description of reference marks used to determine USGS datum. $\quad$ RM1 is a chiseled X on top of the downstream end of the right abutment (elev. $956.17 \mathrm{ft}$, arbitrary survey datum). RM2 is a chiseled $\mathrm{X}$ on top of the upstream end of the right abutment (elev. $956.29 \mathrm{ft}$, arbitrary survey datum).

\section{Cross-Sections Used in WSPRO Analysis}

\begin{tabular}{cccl}
\hline${ }^{1}$ Cross-section & $\begin{array}{c}\text { Section } \\
\text { Reference } \\
\text { Distance } \\
\text { (SRD) } \text { in feet }\end{array}$ & $\begin{array}{c}{ }^{2} \text { Cross-section } \\
\text { development }\end{array}$ & \multicolumn{1}{c}{ Comments } \\
\hline EXITX & -53 & 1 & Exit section \\
FULLV & 0 & 2 & $\begin{array}{l}\text { Downstream Full-valley } \\
\text { section (Templated from } \\
\text { EXITX) }\end{array}$ \\
BRIDG & 0 & 1 & Bridge section \\
RDWAY & 8 & 1 & Road Grade section \\
APPRO & 58 & 1 & Approach section \\
\hline
\end{tabular}

${ }^{1}$ For location of cross-sections see plan-view sketch included with Level I field form, Appendix E. For more detail on how cross-sections were developed see WSPRO input file. 


\section{Data and Assumptions Used in WSPRO Model}

Hydraulic analyses of the reach were done by use of the Federal Highway Administration's WSPRO step-backwater computer program (Shearman and others, 1986, and Shearman, 1990). The analyses reported herein reflect conditions existing at the site at the time of the study. Furthermore, in the development of the model it was necessary to assume no accumulation of debris or ice at the site. Results of the hydraulic model are presented in the Bridge Hydraulic Summary, appendix B, and figure 7.

Channel roughness factors (Manning's " $n$ ") used in the hydraulic model were estimated using field inspections at each cross section following the general guidelines described by Arcement and Schneider (1989). Final adjustments to the values were made during the modelling of the reach. Channel "n" values for the reach ranged from 0.060 to 0.065 , and overbank " $n$ " values ranged from 0.036 to 0.037 .

Normal depth at the exit section (EXITX) was assumed as the starting water surface. This depth was computed by use of the slope-conveyance method outlined in the user's manual for WSPRO (Shearman, 1990). The slope used was $0.0039 \mathrm{ft} / \mathrm{ft}$, which was estimated from the topographic map (U.S. Geological Survey, 1988). 


\section{Bridge Hydraulics Summary}

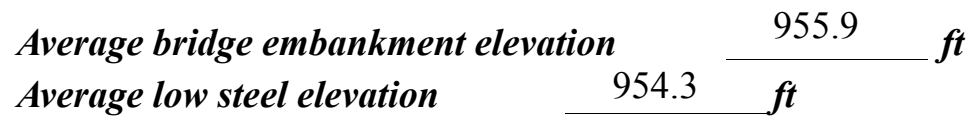

100-year discharge $\quad 3,920 \quad \mathrm{ft}^{3} / \mathrm{s}$

Water-surface elevation in bridge opening $\quad 951.6 \quad f t$

Road overtopping? ___ Yes Discharge over road___ $845 \quad \mathrm{ft}^{3} / \mathrm{s}$

Area of flow in bridge opening $\quad 323 \quad \mathrm{ft}^{2}$

Average velocity in bridge opening $\quad 9.5 \mathrm{ft} / \mathrm{s}$

$\begin{array}{llll}\text { Maximum WSPRO tube velocity at bridge } & 12.0 \mathrm{ft} / \mathrm{s}\end{array}$

Water-surface elevation at Approach section with bridge 953.5

Water-surface elevation at Approach section without bridge $\quad \overline{952.1}$

Amount of backwater caused by bridge $\quad 1.4$ it

500-year discharge $\quad 5,430 \quad \mathrm{ft}^{3} / \mathrm{s}$

Water-surface elevation in bridge opening $\quad 953.0 \mathrm{ft}$

Road overtopping? ___ Yes Discharge over road _ $2,200, \mathrm{it}^{3} / \mathrm{s}$

$\begin{array}{llll}\text { Area of flow in bridge opening } & 377 & \boldsymbol{f t}^{2} & \\ \text { Average velocity in bridge opening } & & 8.6 \quad \mathrm{ft} / \mathrm{s}\end{array}$

Maximum WSPRO tube velocity at bridge 10.8 's

Water-surface elevation at Approach section with bridge

Water-surface elevation at Approach section without bridge $\quad$\begin{tabular}{l}
952.9 \\
\hline
\end{tabular}

Amount of backwater caused by bridge $1.6, t$

Incipient overtopping discharge $\quad 2,260 \mathrm{ft}^{3} / \mathrm{s}$

Water-surface elevation in bridge opening $\quad 950.3 \quad t$

Area of flow in bridge opening $\quad 270 \quad \mathrm{ft}^{2}$

Average velocity in bridge opening $\quad 8.4 \quad \mathrm{ft} / \mathrm{s}$

Maximum WSPRO tube velocity at bridge $\quad 10.5 \mathrm{ft} / \mathrm{s}$

Water-surface elevation at Approach section with bridge

Water-surface elevation at Approach section without bridge

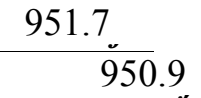

Amount of backwater caused by bridge

0.8 . $t$ 


\section{Scour Analysis Summary}

\section{Special Conditions or Assumptions Made in Scour Analysis}

Scour depths were computed using the general guidelines described in Hydraulic Engineering Circular 18 (Richardson and Davis, 1995). Scour depths were calculated assuming an infinite depth of erosive material and a homogeneous particle-size distribution. The results of the scour analyses for the 100- and 500-year discharges are presented in tables 1 and 2 and the scour depths are shown graphically in figure 8.

Contraction scour for the 100-year, 500-year, and incipient roadway-overtopping discharges was computed by use of the Laursen clear-water contraction scour equation (Richardson and Davis, 1995, p. 32, equation 20). Variables for the live-bed contraction scour equation include the bottom width, depth, and discharge in the bridge opening and in the approach main channel, the shear velocity in the approach channel, and the fall velocity of the median-sized particles of the bed material.

Abutment scour for the right abutment was computed by use of the Froehlich equation (Richardson and Davis, 1995, p. 48, equation 28). Variables for the Froehlich equation include the Froude number of the flow approaching the embankments, the length of the embankment blocking flow, and the depth of flow approaching the embankment less any roadway overtopping.

Because the influence of scour processes on the stone-fill embankment material on the right abutment is uncertain, the scour depth at the vertical concrete abutment wall is unknown. Therefore, the total scour depths were applied for the entire embankment area below the elevation at the toe of each embankment, as shown in figure 8 .

Scour at the left abutment was computed by use of the HIRE equation (Richardson and Davis, 1995, p. 49, equation 29) because the HIRE equation is recommended when the length to depth ratio of the embankment blocking flow exceeds 25 . The variables used by the HIRE abutment-scour equation are defined the same as those defined for the Froehlich abutment-scour equation. 
Scour Results

Contraction scour:

Main channel

Live-bed scour

Clear-water scour

Depth to armoring

Left overbank

Right overbank

Local scour:

Abutment scour

Left abutment

Right abutment

Pier scour

Pier 1

Pier 2

Pier 3
Abutments:

Left abutment

Right abutment

Piers:

Pier 1

Pier 2 100-year discharge
Incipient

500-year overtopping discharge discharge

(Scour depths in feet)

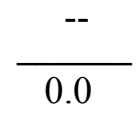

$2.60 .9^{-}$
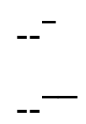

$--$

$7.56 .7^{-}$

13.0

$10.7-$
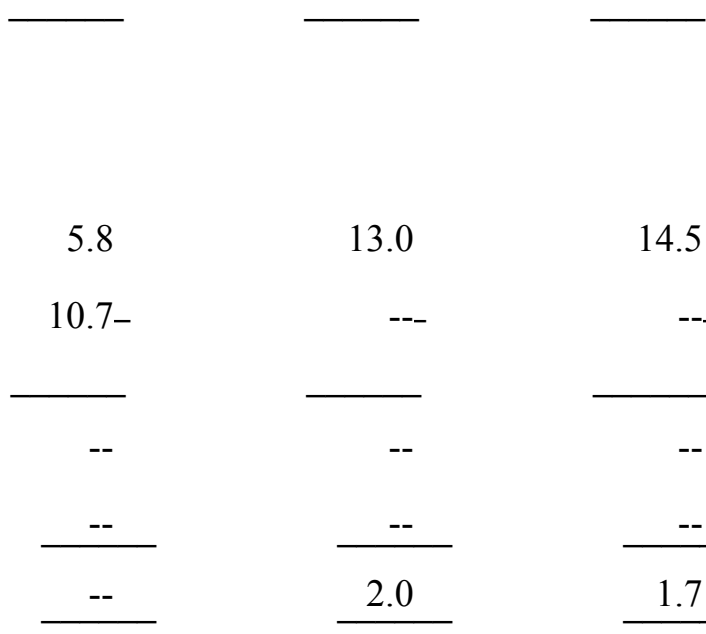

\section{Riprap Sizing}

100-year
discharge

1.4

1.4
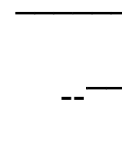

$--$
Incipient

500-year discharge ( $D_{50}$ in feet) 2.0

1.7

overtopping discharge
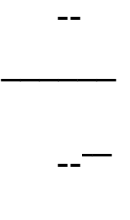

$--$
14.5

$-$

$-$

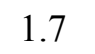




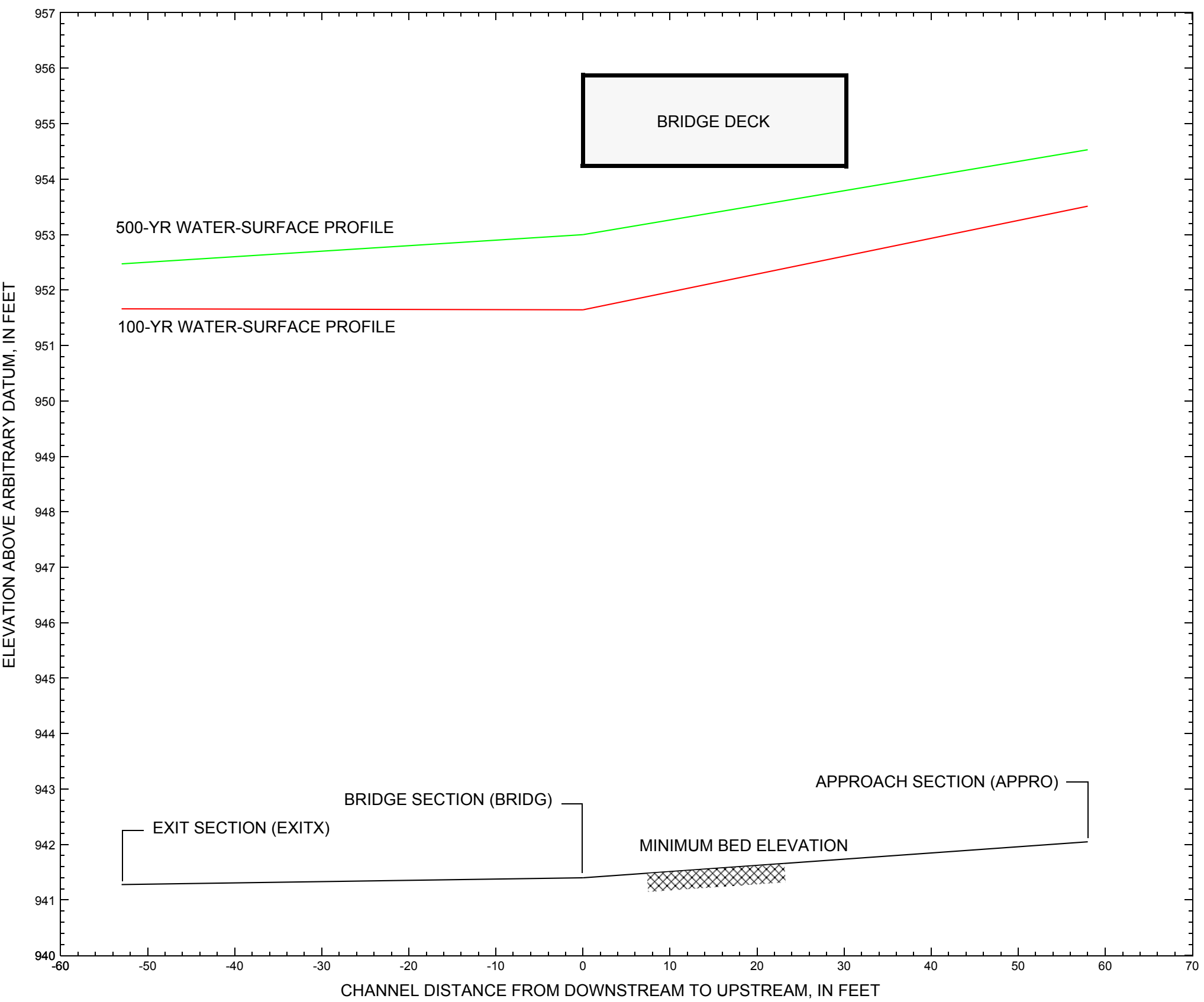

Figure 7. Water-surface profiles for the 100- and 500-year discharges at structure BURKTH00560020 on Town Highway 56, crossing the East Branch Passumpsic River, Burke, Vermont. 


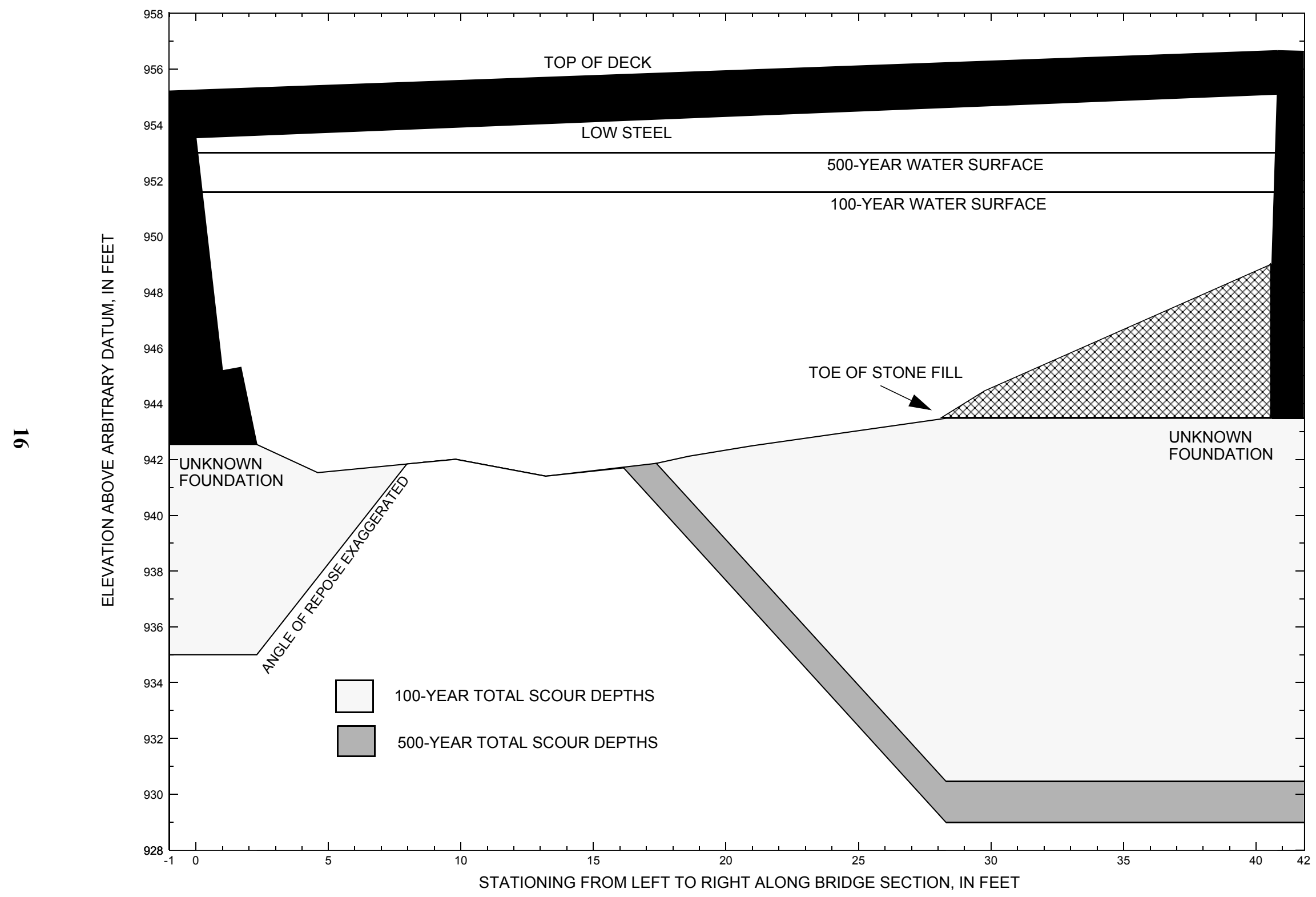

Figure 8. Scour elevations for the 100- and 500-year discharges at structure BURKTH00560020 on Town Highway 56, crossing the East Branch Passumpsic River, Burke, Vermont. 


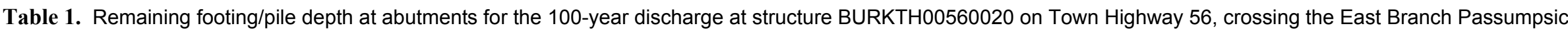
River, Burke, Vermont.

[VTAOT, Vermont Agency of Transportation; --, no data]

\begin{tabular}{|c|c|c|c|c|c|c|c|c|c|c|c|}
\hline Description & Station ${ }^{1}$ & $\begin{array}{c}\text { VTAOT } \\
\text { minimum } \\
\text { low-chord } \\
\text { elevation } \\
\text { (feet) }\end{array}$ & $\begin{array}{c}\text { Surveyed } \\
\text { minimum } \\
\text { low-chord } \\
\text { elevation } \\
\text { (feet) }\end{array}$ & $\begin{array}{c}\text { Bottom of } \\
\text { footing/pile } \\
\text { elevation }{ }^{2} \\
\text { (feet) }\end{array}$ & $\begin{array}{c}\text { Channel } \\
\text { elevation at } \\
\text { abutment/ } \\
\text { pier }^{2} \\
\text { (feet) }\end{array}$ & $\begin{array}{l}\text { Contraction } \\
\text { scour depth } \\
\text { (feet) }\end{array}$ & $\begin{array}{l}\text { Abutment } \\
\text { scour } \\
\text { depth } \\
\text { (feet) }\end{array}$ & $\begin{array}{l}\text { Pier } \\
\text { scour } \\
\text { depth } \\
\text { (feet) }\end{array}$ & $\begin{array}{c}\text { Depth of } \\
\text { total scour } \\
\text { (feet) }\end{array}$ & $\begin{array}{c}\text { Elevation of } \\
\text { scour }^{2,3} \\
\text { (feet) }\end{array}$ & $\begin{array}{c}\text { Remaining } \\
\text { footing/pile } \\
\text { depth } \\
\text { (feet) }\end{array}$ \\
\hline \multicolumn{12}{|c|}{100 -year discharge is 3,920 cubic-feet per second } \\
\hline Left abutment & 0.0 & -- & 953.5 & -- & 942.5 & 0.0 & 7.5 & -- & 7.5 & 935.0 & -- \\
\hline Toe of stone fill & 28.3 & -- & -- & -- & 943.5 & 0.0 & 13.0 & -- & 13.0 & -- & -- \\
\hline Right abutment & 40.8 & -- & 955.1 & -- & 949.0 & -- & -- & -- & -- & 930.5 & -- \\
\hline
\end{tabular}

1.Measured along the face of the most constricting side of the bridge.

2.Arbitrary datum for this study.

3.Depth of total scour is computed at the toe of stone-fill and elevation of scour pertains to the area between the toe of stone-fill and the right abutment

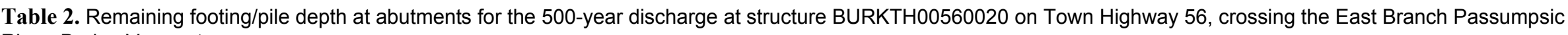
River, Burke, Vermont.

[VTAOT, Vermont Agency of Transportation; --, no data]

\begin{tabular}{|c|c|c|c|c|c|c|c|c|c|c|c|}
\hline Description & Station $^{1}$ & $\begin{array}{l}\text { VTAOT } \\
\text { minimum } \\
\text { low-chord } \\
\text { elevation } \\
\text { (feet) }\end{array}$ & $\begin{array}{l}\text { Surveyed } \\
\text { minimum } \\
\text { low-chord } \\
\text { elevation }{ }^{2} \\
\text { (feet) }\end{array}$ & $\begin{array}{c}\text { Bottom of } \\
\text { footing/pile } \\
\text { elevation }{ }^{2} \\
\text { (feet) }\end{array}$ & $\begin{array}{c}\text { Channel } \\
\text { elevation at } \\
\text { abutment/ } \\
\text { pier }^{2} \\
\text { (feet) }\end{array}$ & $\begin{array}{l}\text { Contraction } \\
\text { scour depth } \\
\text { (feet) }\end{array}$ & $\begin{array}{l}\text { Abutment } \\
\text { scour } \\
\text { depth } \\
\text { (feet) }\end{array}$ & $\begin{array}{l}\text { Pier } \\
\text { scour } \\
\text { depth } \\
\text { (feet) }\end{array}$ & $\begin{array}{l}\text { Depth of } \\
\text { total scour } \\
\text { (feet) }\end{array}$ & $\begin{array}{c}\text { Elevation of } \\
\text { scour }^{2,3} \\
\text { (feet) }\end{array}$ & $\begin{array}{c}\text { Remaining } \\
\text { footing/pile } \\
\text { depth } \\
\text { (feet) }\end{array}$ \\
\hline \multicolumn{12}{|c|}{500 -year discharge is 5,430 cubic-feet per second } \\
\hline Left abutment & 0.0 & -- & 953.5 & -- & 942.5 & 0.0 & 6.7 & -- & 6.7 & 935.8 & -- \\
\hline Toe of stone fill & 28.3 & -- & -- & -- & 943.5 & 0.0 & 14.5 & -- & 14.5 & -- & -- \\
\hline Right abutment & 40.8 & -- & 955.1 & -- & 949.0 & -- & -- & -- & -- & 929.0 & -- \\
\hline
\end{tabular}

1.Measured along the face of the most constricting side of the bridge.

2.Arbitrary datum for this study.

3.Depth of total scour is computed at the toe of stone-fill and elevation of scour pertains to the area between the toe of stone-fill and the right abutment 


\section{SELECTED REFERENCES}

Arcement, G.J., Jr., and Schneider, V.R., 1989, Guide for selecting Manning's roughness coefficients for natural channels and flood plains:

U.S. Geological Survey Water-Supply Paper 2339, 38 p.

Barnes, H.H., Jr., 1967, Roughness characteristics of natural channels: U.S. Geological Survey Water-Supply Paper 1849,213 p.

Benson, M. A., 1962, Factors Influencing the Occurrence of Floods in a Humid Region of Diverse Terrain: U.S. Geological Survey WaterSupply Paper 1580-B, 64 p.

Brown, S.A. and Clyde, E.S., 1989, Design of riprap revetment: Federal Highway Administration Hydraulic Engineering Circular No. 11, Publication FHWA-IP-89-016, 156 p.

Federal Emergency Management Agency, 1980, Flood Insurance Study, Town of Burke, Caledonia County, Vermont: Washington, D.C., December 1979.

Federal Highway Administration, 1983, Runoff estimates for small watersheds and development of sound design: Federal Highway Administration Report FHWA-RD-77-158.

Federal Highway Administration, 1993, Stream Stability and Scour at Highway Bridges: Participant Workbook: Federal Highway Administration Report FHWA-HI-91-011.

Froehlich, D.C., 1989, Local scour at bridge abutments in Ports, M.A., ed., Hydraulic Engineering--Proceedings of the 1989 National Conference on Hydraulic Engineering: New York, American Society of Civil Engineers, p. 13-18.

Hayes, D.C.,1993, Site selection and collection of bridge-scour data in Delaware, Maryland, and Virginia: U.S. Geological Survey WaterResources Investigation Report 93-4017, 23 p.

Interagency Advisory Committee on Water Data, 1982, Guidelines for determining flood flow frequency: U.S. Geological Survey, Bulletin 17B of the Hydrology Subcommittee, 190 p.

Johnson, C.G. and Tasker, G.D.,1974, Progress report on flood magnitude and frequency of Vermont streams: U.S. Geological Survey OpenFile Report 74-130, 37 p.

Lagasse, P.F., Schall, J.D., Johnson, F., Richardson, E.V., Chang, F., 1995, Stream Stability at Highway Structures: Federal Highway Administration Hydraulic Engineering Circular No. 20, Publication FHWA-IP-90-014, 144 p.

Laursen, E.M., 1960, Scour at bridge crossings: Journal of the Hydraulics Division, American Society of Civil Engineers, v. 86, no. HY2, p. 39-53.

Potter, W. D., 1957a, Peak rates of runoff in the Adirondack, White Mountains, and Maine woods area, Bureau of Public Roads

Potter, W. D., 1957b, Peak rates of runoff in the New England Hill and Lowland area, Bureau of Public Roads

Richardson, E.V. and Davis, S.R., 1995, Evaluating scour at bridges: Federal Highway Administration Hydraulic Engineering Circular No. 18, Publication FHWA-IP-90-017, 204 p.

Richardson, E.V., Simons, D.B., and Julien, P.Y., 1990, Highways in the river environment: Federal Highway Administration Publication FHWA-HI-90-016.

Ritter, D.F., 1984, Process Geomorphology: W.C. Brown Co., Debuque, Iowa, 603 p.

Shearman, J.O., 1990, User's manual for WSPRO--a computer model for water surface profile computations: Federal Highway Administration Publication FHWA-IP-89-027, 187 p.

Shearman, J.O., Kirby, W.H., Schneider, V.R., and Flippo, H.N., 1986, Bridge waterways analysis model; research report: Federal Highway Administration Publication FHWA-RD-86-108, 112 p.

Talbot, A.N., 1887, The determination of water-way for bridges and culverts.

U.S. Geological Survey, 1988, West Burke, Vermont 7.5 Minute Series quadrangle map: U.S. Geological Survey Topographic Maps, Scale $1: 24,000$. 


\section{APPENDIX A: \\ WSPRO INPUT FILE}




\section{WSPRO INPUT FILE}

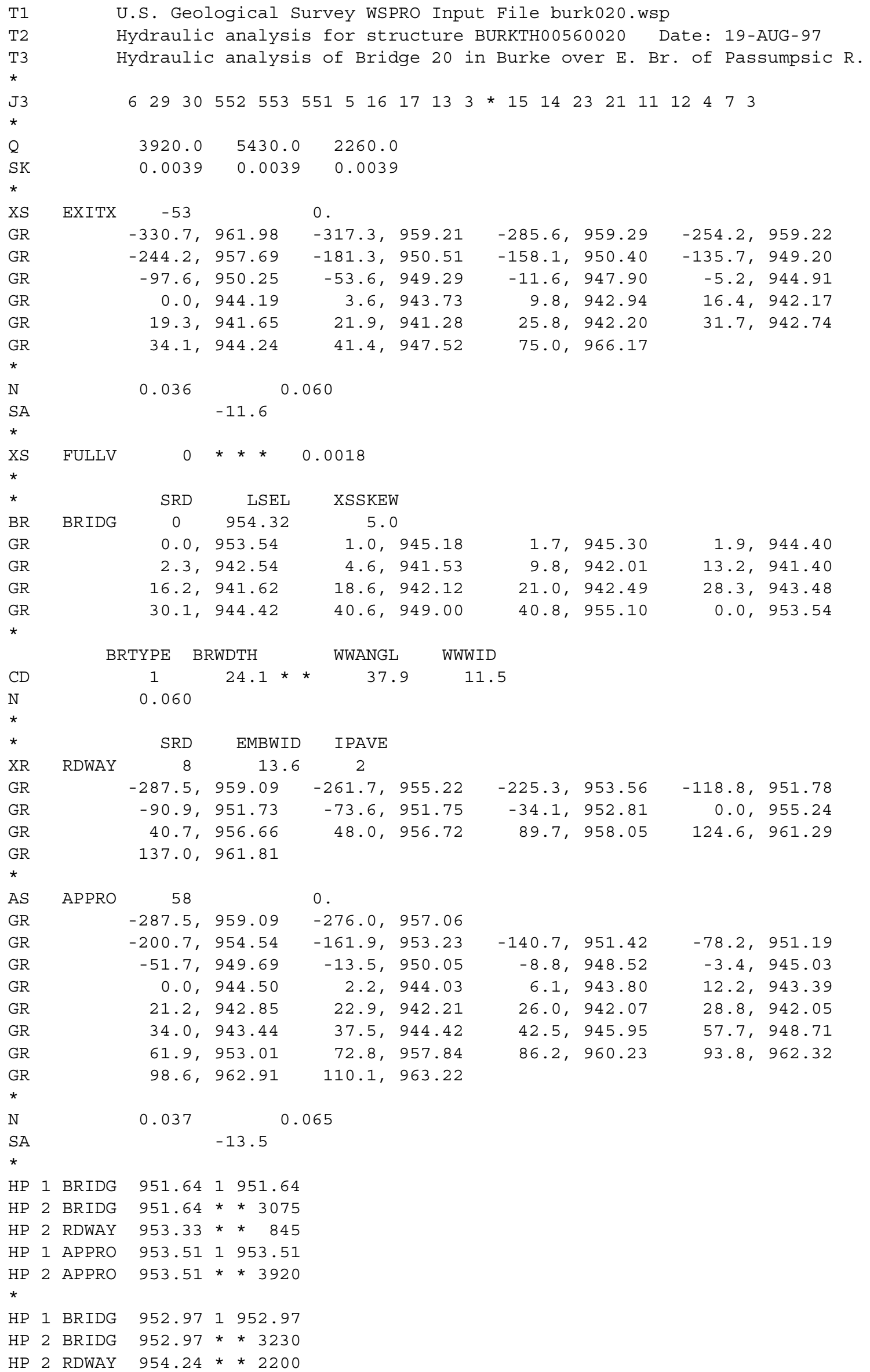




\section{APPENDIX B: \\ WSPRO OUTPUT FILE}




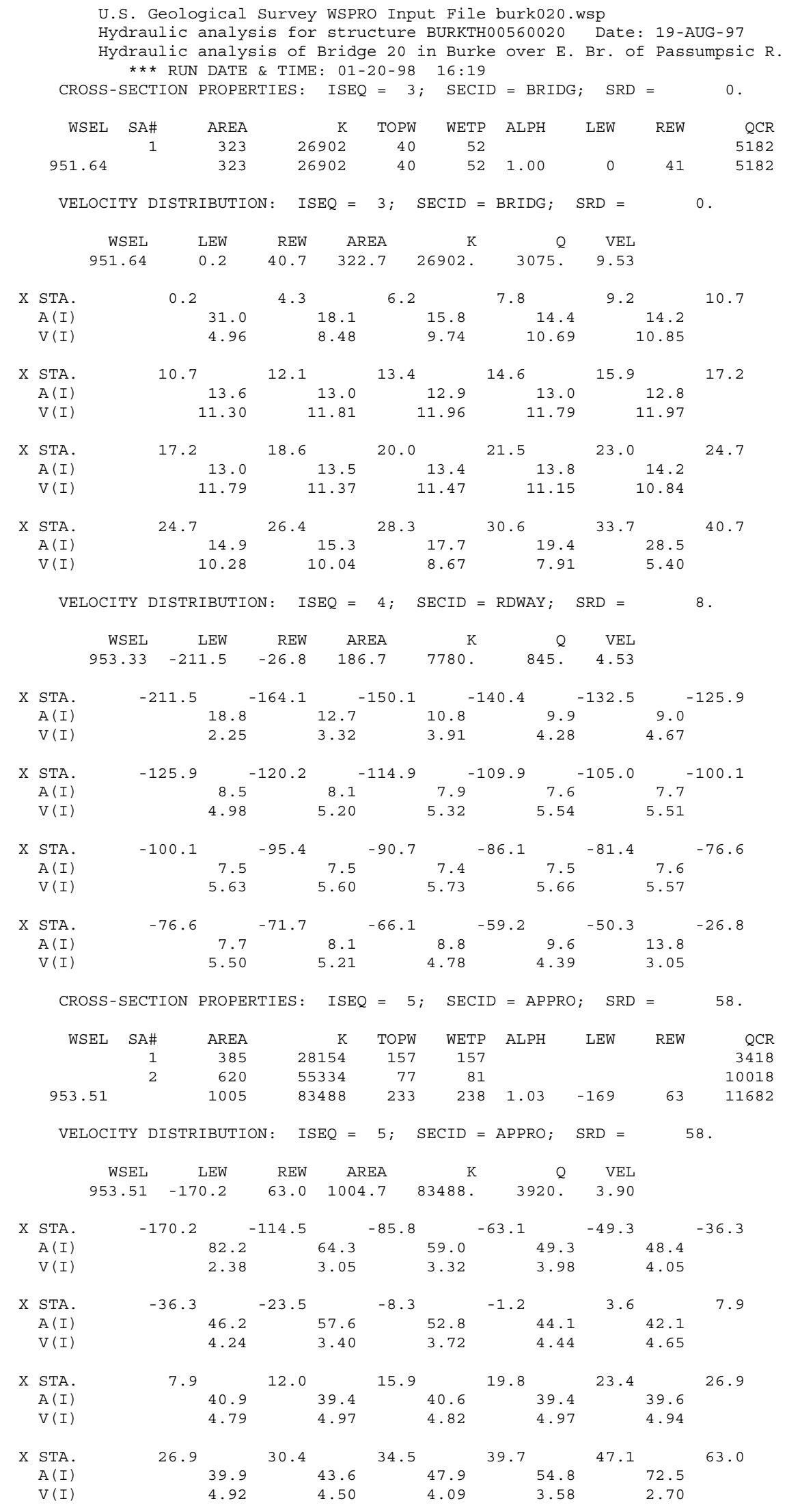


WSPRO OUTPUT FILE (continued)

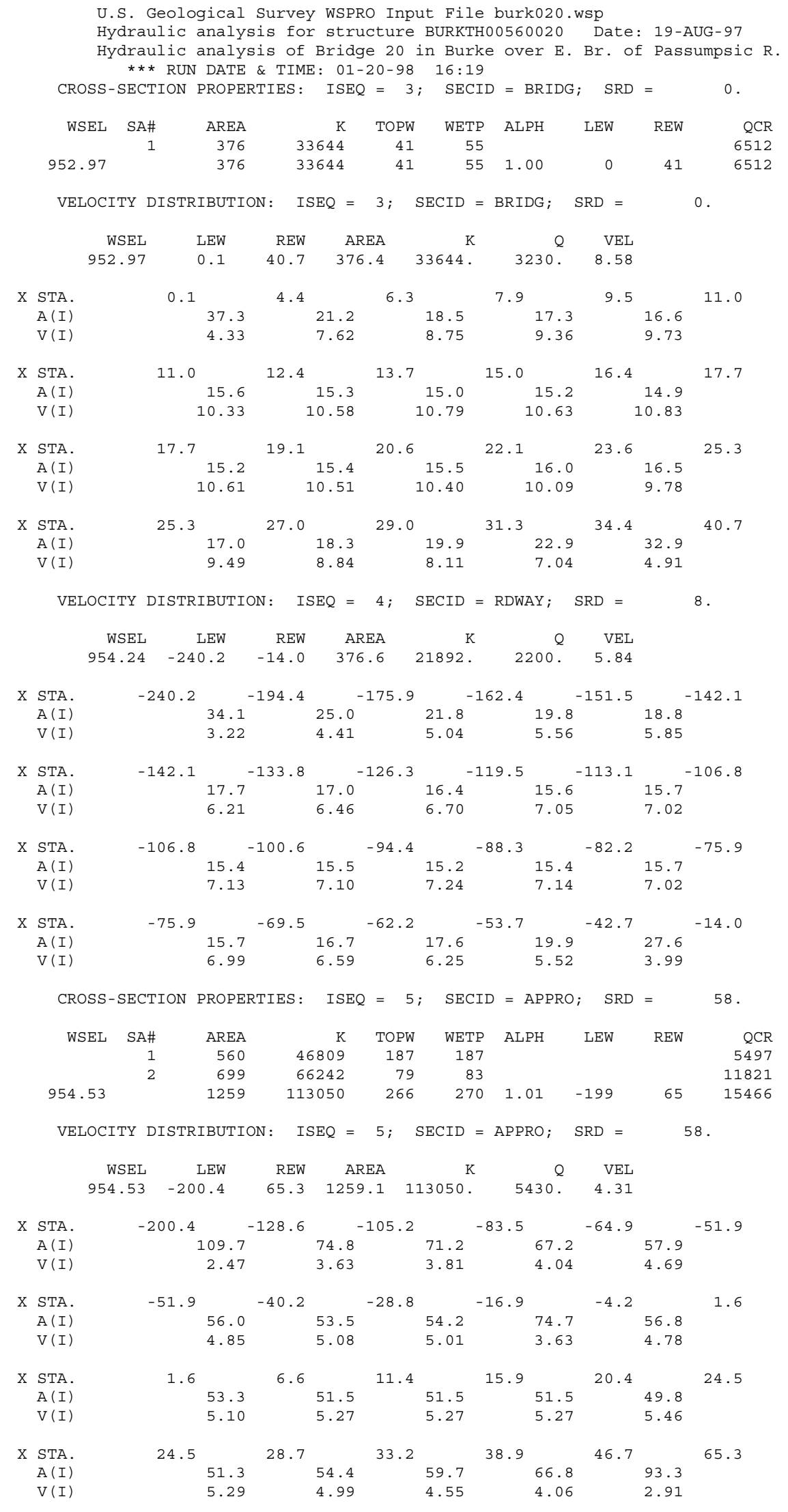


WSPRO OUTPUT FILE (continued)

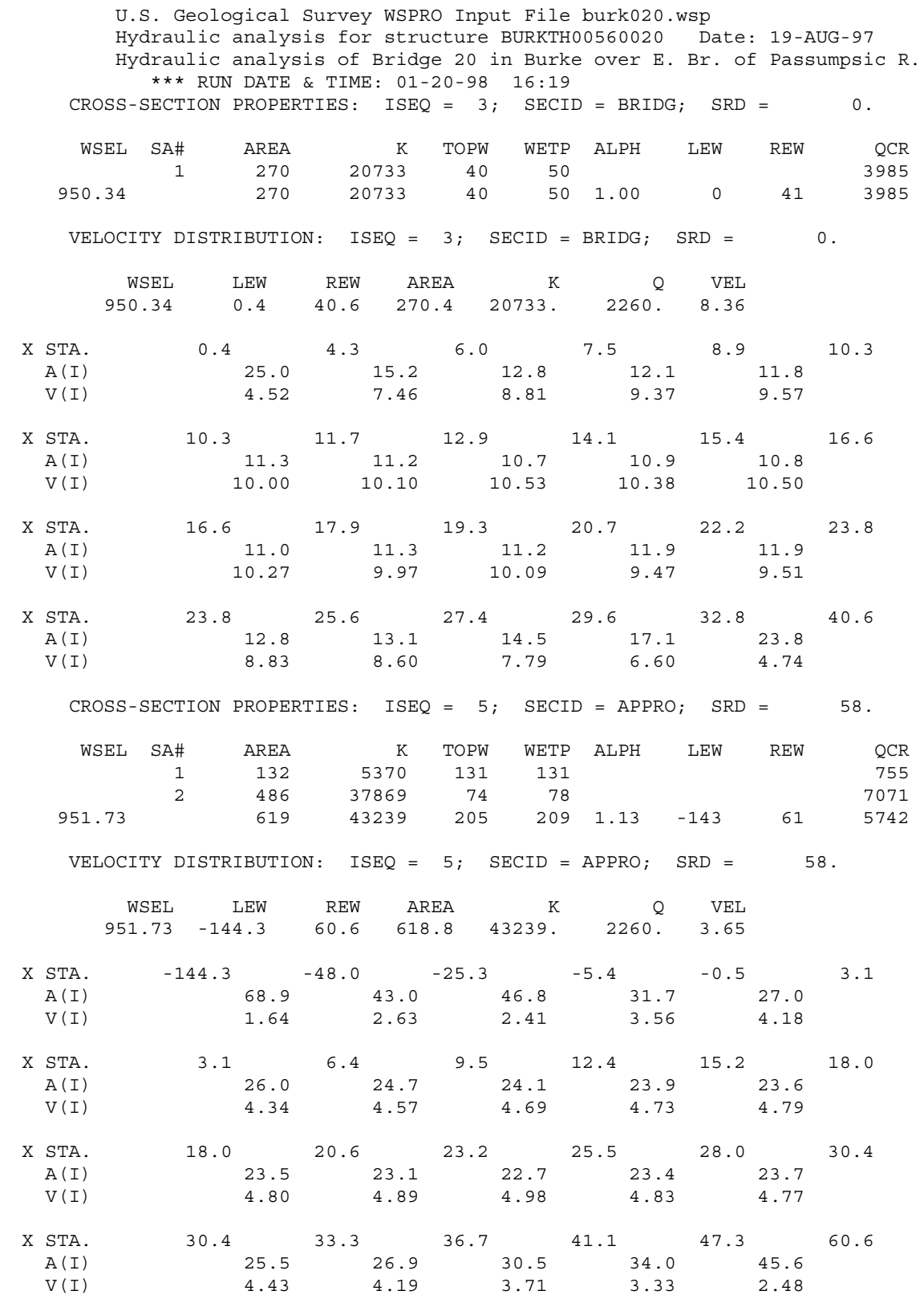


WSPRO OUTPUT FILE (continued)

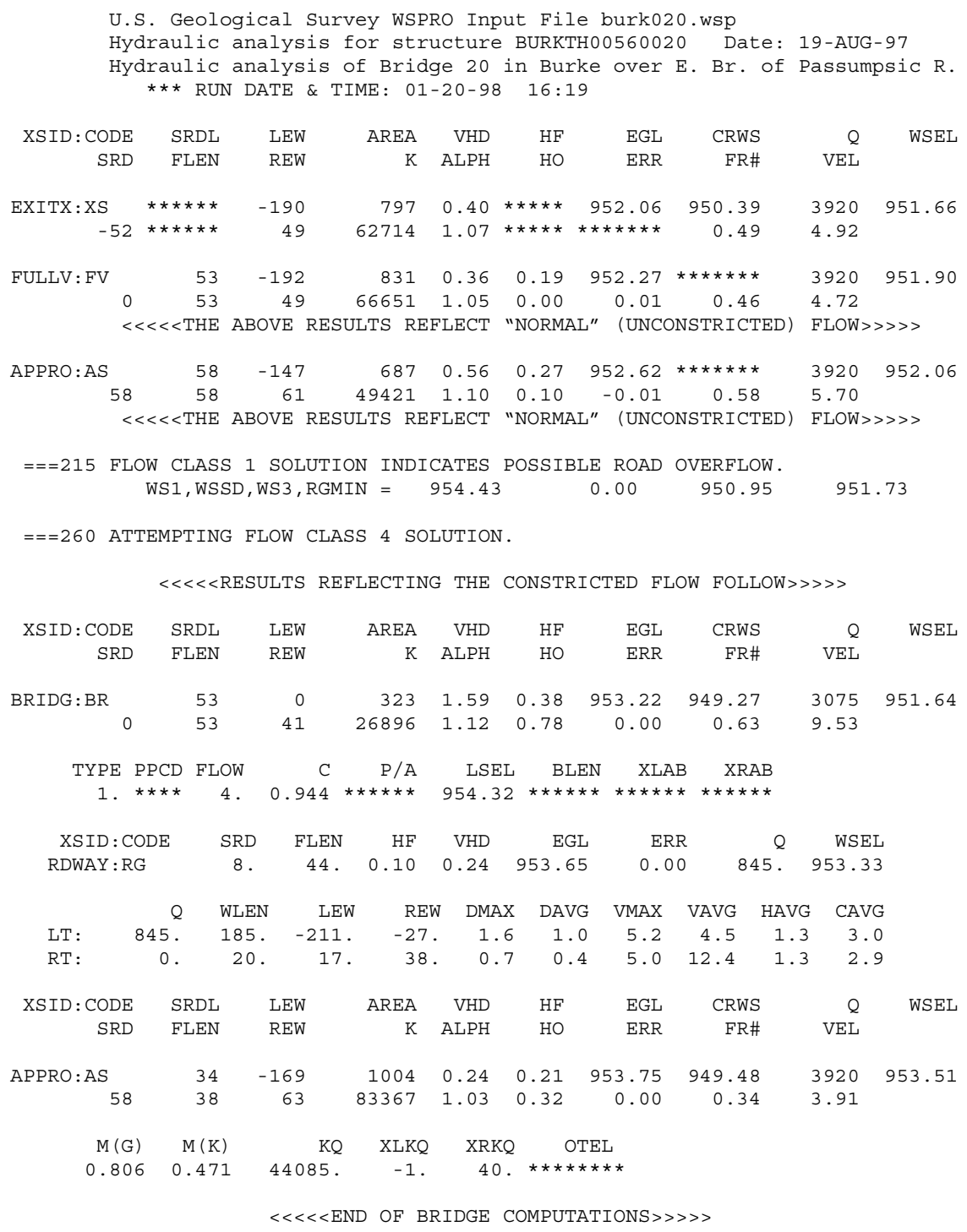

FIRST USER DEFINED TABLE.

\begin{tabular}{|c|c|c|c|c|c|c|c|c|}
\hline XSID : CODE & SRD & LEW & REW & $\mathrm{Q}$ & K & AREA & VEL & WSEL \\
\hline EXITX:XS & -53 & -191. & 49. & 3920. & 62714 & 797. & 4.92 & 951.66 \\
\hline FULLV : FV & 0 . & -193. & 49. & 3920. & 66651. & 831. & 4.72 & 951.90 \\
\hline BRIDG : BR & 0 . & 0 . & 41 & 3075 . & 26896 . & 323. & 9.53 & 951.64 \\
\hline RDWAY : RG & 8. & $* * * * * *$ & 845 . & 845 . & $\star \star \star \star * \star \star * *$ & 0 . & 2.00 & 953.33 \\
\hline APPRO: AS & 58. & -170. & 63. & 3920. & 83367. & 1004. & 3.91 & 953.51 \\
\hline XSID : CODE & XLKQ & XRKQ & & & & & & \\
\hline APPRO:AS & -1 & 40. & 44085 & & & & & \\
\hline
\end{tabular}

SECOND USER DEFINED TABLE.

$\begin{array}{lcrrrrrrrr}\text { XSID : CODE } & \text { CRWS } & \text { FR\# } & \text { YMIN } & \text { YMAX } & \text { HF } & \text { HO } & \text { VHD } & \text { EGL } & \text { WSEL } \\ \text { EXITX:XS } & 950.39 & 0.49 & 941.28 & 966.17 * * * * * * * * * * & 0.40 & 952.06 & 951.66 \\ \text { FULLV:FV } & * * * * * * * * & 0.46 & 941.38 & 966.27 & 0.19 & 0.00 & 0.36 & 952.27 & 951.90 \\ \text { BRIDG:BR } & 949.27 & 0.63 & 941.40 & 955.10 & 0.38 & 0.78 & 1.59 & 953.22 & 951.64 \\ \text { RDWAY:RG } & * * * * * * * * * * * * * * * * & 951.73 & 961.81 & 0.10 * * * * * * & 0.24 & 953.65 & 953.33 \\ \text { APPRO:AS } & 949.48 & 0.34 & 942.05 & 963.22 & 0.21 & 0.32 & 0.24 & 953.75 & 953.51\end{array}$


WSPRO OUTPUT FILE (continued)

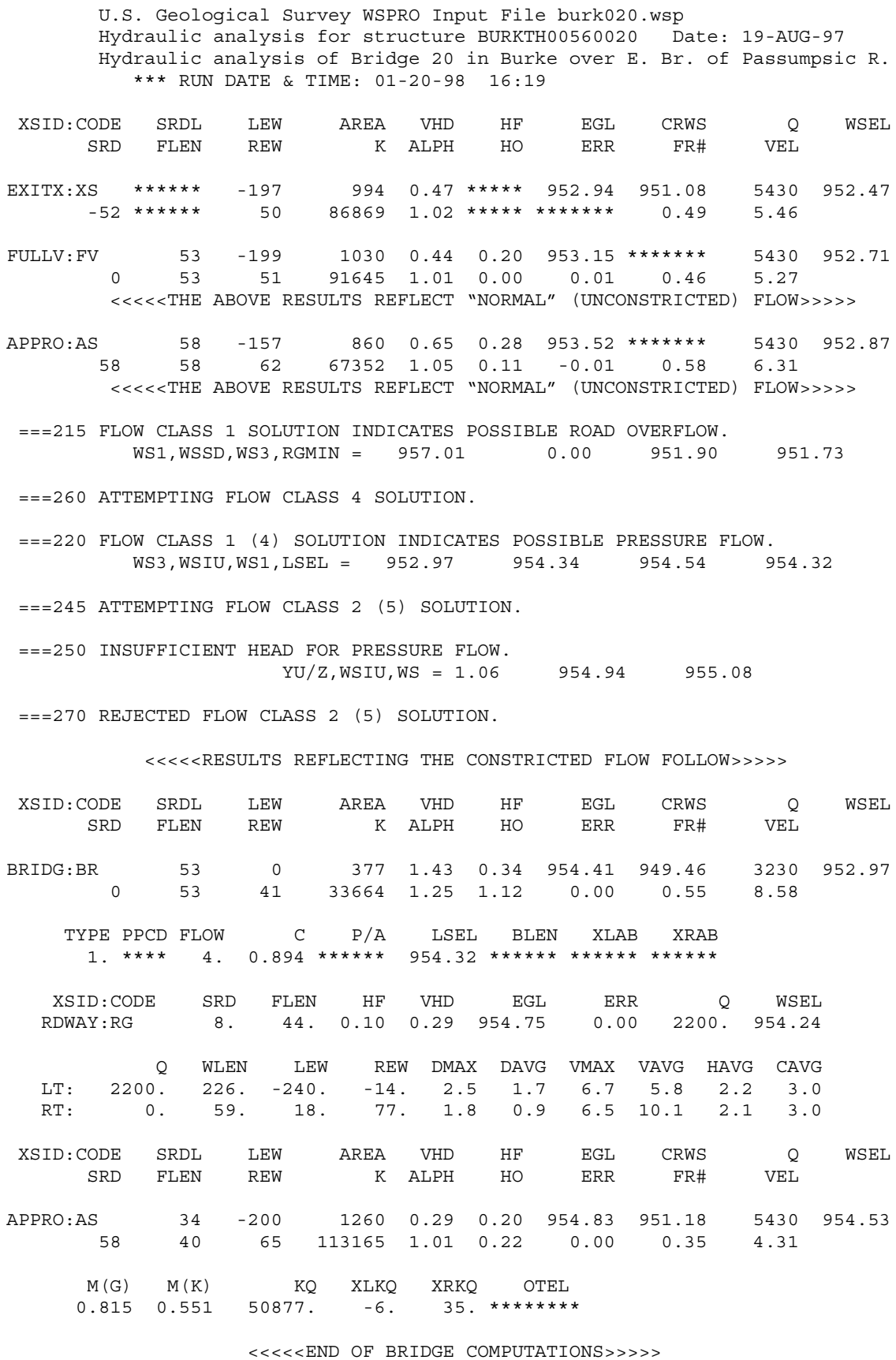

FIRST USER DEFINED TABLE.

\begin{tabular}{|c|c|c|c|c|c|c|c|c|}
\hline XSID : CODE & SRD & LEW & REW & $Q$ & K & AREA & VEL & WSEL \\
\hline EXITX:XS & -53. & -198. & 50. & 5430. & 86869. & 994. & 5.46 & 952.47 \\
\hline FULLV : FV & 0 . & -200 & 51. & 5430. & 91645 . & 1030. & 5.27 & 952.71 \\
\hline BRIDG : BR & 0 . & 0 . & 41. & 3230. & 33664 . & 377 . & 8.58 & 952.97 \\
\hline RDWAY : RG & 8. & $* * * * *$ & 2200 . & 2200 & $\star \star \star \star \star * \star * *$ & 0 . & 2.00 & 954.24 \\
\hline APPRO: AS & 58. & -201. & 65. & 5430. & 113165. & 1260 . & 4.31 & 954.5 \\
\hline XSID : CODE & XLKQ & XRKQ & & & & & & \\
\hline APPRO: AS & -6 . & 35. & 50877 & & & & & \\
\hline
\end{tabular}

SECOND USER DEFINED TABLE.

\begin{tabular}{lcrrrrrrrr} 
XSID : CODE & CRWS & FR\# & YMIN & \multicolumn{1}{c}{ YMAX } & HF & HO & VHD & EGL & WSEL \\
EXITX:XS & 951.08 & 0.49 & 941.28 & $966.17 * * * * * * * * * *$ & 0.47 & 952.94 & 952.47 \\
FULLV:FV & $* * * * * * * *$ & 0.46 & 941.38 & 966.27 & 0.20 & 0.00 & 0.44 & 953.15 & 952.71 \\
BRIDG:BR & 949.46 & 0.55 & 941.40 & 955.10 & 0.34 & 1.12 & 1.43 & 954.41 & 952.97 \\
RDWAY:RG & $* * * * * * * * * * * * * * * *$ & 951.73 & 961.81 & $0.10 * * * * * *$ & 0.29 & 954.75 & 954.24 \\
APPRO:AS & 951.18 & 0.35 & 942.05 & 963.22 & 0.20 & 0.22 & 0.29 & 954.83 & 954.53
\end{tabular}


WSPRO OUTPUT FILE (continued)

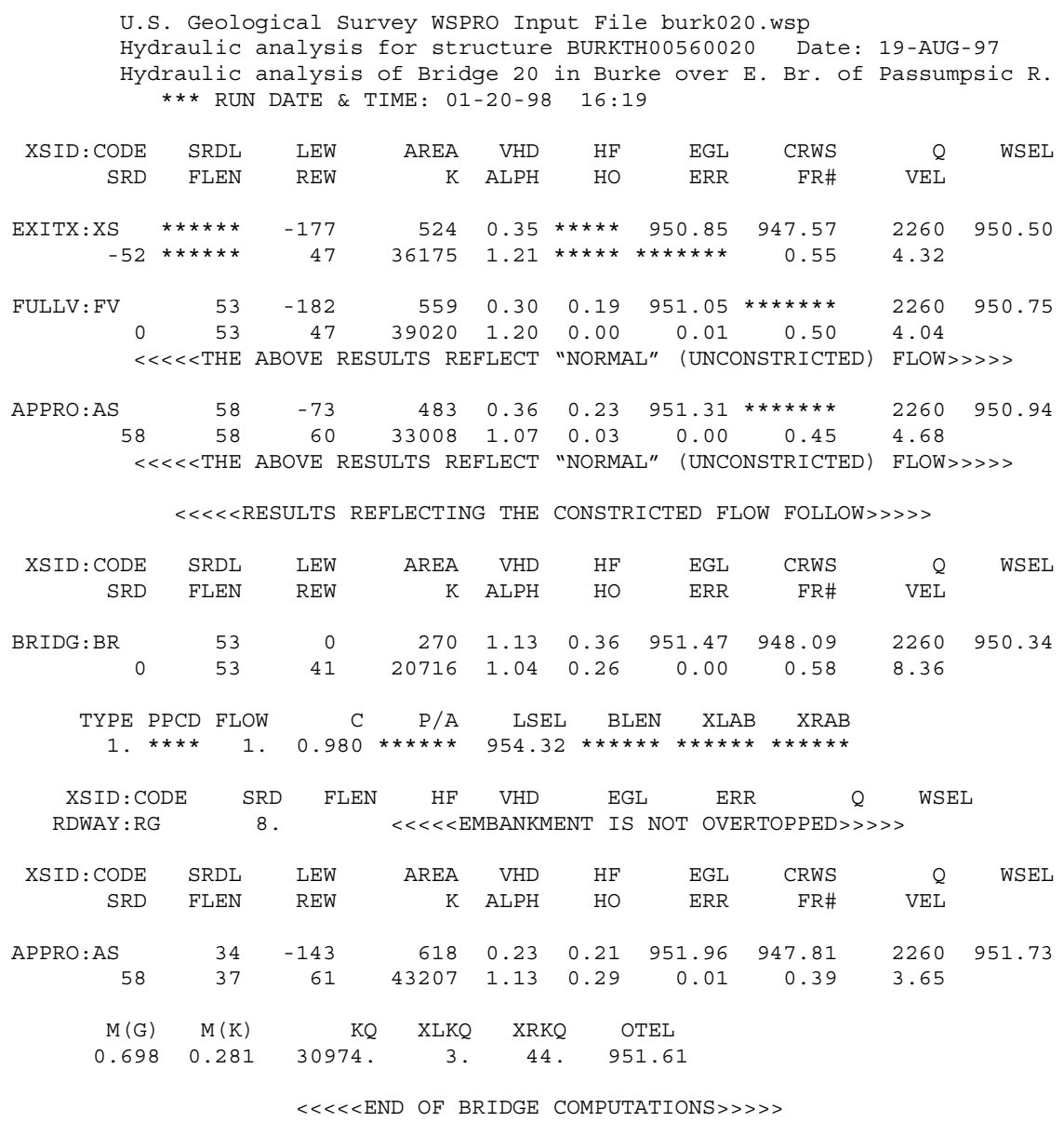

FIRST USER DEFINED TABLE.

\begin{tabular}{|c|c|c|c|c|c|c|c|c|}
\hline XSID : CODE & SRD & LEW & REW & Q & K & AREA & VEL & WSEL \\
\hline EXITX : XS & -53 & -178 & 47. & 2260 . & 36175 . & 524 & 4.32 & 950.50 \\
\hline FULLV : FV & 0 . & -183. & 47. & 2260 . & 39020 . & 559. & 4.04 & 950.75 \\
\hline BRIDG : BR & 0 . & 0 . & 41. & 2260 . & 20716 . & 270 . & 8.36 & 950.34 \\
\hline RDWAY : RG & \multicolumn{3}{|c|}{ 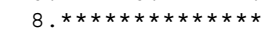 } & \multicolumn{3}{|c|}{ 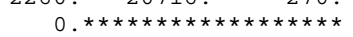 } & \multicolumn{2}{|c|}{$2.00 * \star * \star * * \star *$} \\
\hline APPRO : AS & 58 . & -144 & 61. & 2260 . & 43207 . & 618 & 3.65 & 951.73 \\
\hline XSID : CODE & XLKQ & $\mathrm{XRKQ}$ & & & & & & \\
\hline APPRO: AS & 3. & 44. & 3097 & & & & & \\
\hline
\end{tabular}

SECOND USER DEFINED TABLE.

\begin{tabular}{|c|c|c|c|c|c|c|c|c|c|}
\hline XSID : CODI & CRWS & FR\# & YMIN & YMAX & $\mathrm{HF}$ & $\mathrm{HO}$ & VHD & EGL & WSEL \\
\hline EXITX:XS & 947.57 & .55 & 941.28 & $966.17 *$ & $x$ & *** & 0.35 & 950.85 & 950.50 \\
\hline ELLV : FV & 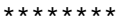 & .50 & 941.38 & 966.27 & 0.19 & 0.00 & 0. & 951.05 & 50.75 \\
\hline BRIDG : BR & 948.09 & .58 & 941.40 & 955.10 & 0.36 & 0.26 & 1.13 & 951.47 & 950.34 \\
\hline RDWAY : RG & 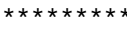 & $\star \star \star *$ & 951.73 & $961.81 *$ & $* * * *$ & $\star \star *$ & $\star \star * *$ & $\star * \star * *$ & $* * *$ \\
\hline PPRO : AS & 947.81 & 0.39 & 942.05 & 963.22 & 0.21 & 0.29 & 0.23 & 951.96 & 951.73 \\
\hline
\end{tabular}




\section{APPENDIX C:}

\section{BED-MATERIAL PARTICLE-SIZE DISTRIBUTION}




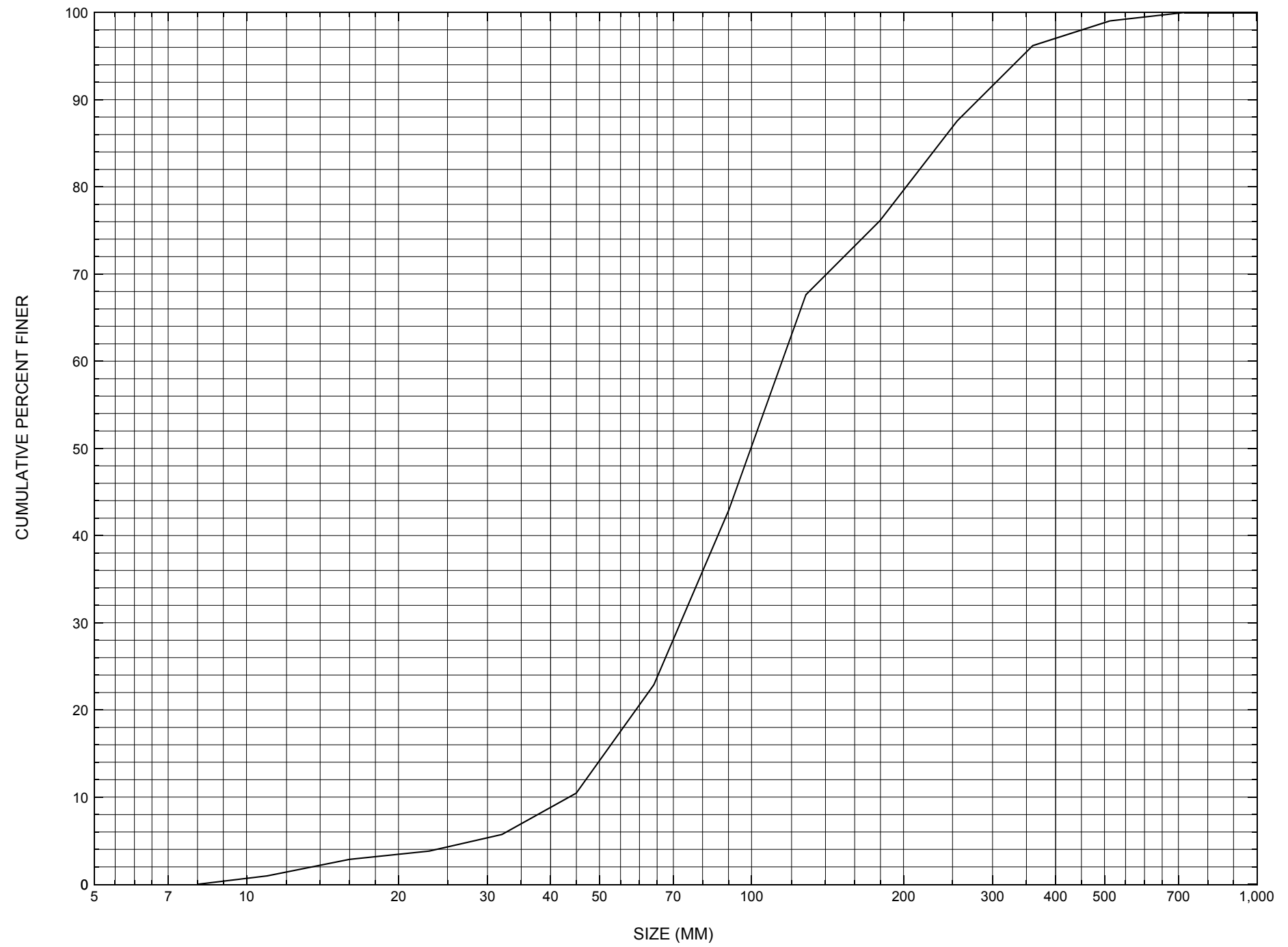

Appendix C. Bed material particle-size distribution for a pebble count in the channel 30 feet upstream of the approach of structure BURKTH00560020, in Burke, Vermont. 


\section{APPENDIX D: \\ HISTORICAL DATA FORM}




\section{Structure Number BURKTH00560020}

\section{General Location Descriptive}

Data collected by (First Initial, Full last name) $\mathbf{E}$. BOEHMLER

Date $(M M / D D / Y Y) \_\mathbf{0 3} / \underline{24} / \underline{95}$

Highway District Number (I - 2; nn) $\mathbf{0 7}$

Town (FIPS place code; I - 4; nnnnn) $\mathbf{1 0 4 5 0}$

Waterway ( $($ - 6) EAST BR. PASSUMPSIC RIVER

Route Number TH056

Topographic Map West Burke

Latitude (I - 16; nnnn.n) $\mathbf{4 4 3 8 1}$
County (FIPS county code; I - 3; nnn)

Mile marker (I - 11; nnn.nnn) $\mathbf{0 0 0 0 0 0}$

Road Name (I - 7): -

Vicinity (I - 9) 0.1 MI JCT TH 56 + VT114

Hydrologic Unit Code: $\mathbf{0 1 0 8 0 1 0 2}$

Longitude (i - 17; nnnnn.n) $\mathbf{7 1 5 3 8}$

\section{Select Federal Inventory Codes}

FHWA Structure Number (I - 8) $\mathbf{1 0 0 3 0 2 0 0 2 0 0 3 0 2}$

Maintenance responsibility $(I-21 ; n n) \_$03 _ Maximum span length $(I-48$; $n n n n) \underline{\mathbf{0 0 4 4}}$

Year built (I - 27; YYYY) 1955

Structure length (I - 49; nnnnnn) $\underline{000046}$

Average daily traffic, ADT (I - 29; nnnnnn) 000020 Deck Width (I - 52; nn.n) 136

Year of ADT (I - 30; YY) $\mathbf{9 2}$

Channel \& Protection $(I-61 ; n) \underline{5}$

Opening skew to Roadway $(I-34 ; n n) \quad \mathbf{0 0}$

Waterway adequacy $(I-71 ; n)$

Operational status $(I-41 ; X) \quad \mathbf{A}$

Underwater Inspection Frequency $(I-92 B ; X Y Y) \_\mathbf{N}$

Structure type (I- 43; nnn) $\mathbf{3 0 2}$

Year Reconstructed (I - 106) $\mathbf{0 0 0 0}$

Approach span structure type (I - 44; nnn) $\mathbf{0 0 0}$

Clear span (nnn.n ft) _

Number of spans (I - 45; nnn) $\mathbf{0 0 1}$

Vertical clearance from streambed (nnn.n ft) $\underline{\mathbf{0 1 0 . 2}}$

Number of approach spans (I - 46; nnnn) $\mathbf{0 0 0 0}$

Waterway of full opening $\left(n n n . n \mathrm{ft}^{2}\right)$

Comments:

The structural inspection report of 9/19/94 indicates that the structure is a steel, stringer-type bridge with a wooden plank deck. The right abutment and its wingwalls are constructed with concrete, while the left abutment and wingwalls are "laid-up" stone blocks. The stone blocks of the left abutment are capped with concrete. The cap has a few fine cracks and leaks, and a vertical settlement crack at the center-line of the roadway. Small areas of the stone chinking are missing on the abutment face. The report mentions that "boulder fill" has been piled in front of the right abutment and its wingwalls. Similarly, the same stone fill is evident on the stream banks upstream and downstream. The report indicates (Continued, page 33) 


\section{Bridge Hydrologic Data}

Is there hydrologic data available? $\underline{\mathbf{N}}$ if No, type ctrl-n $h \quad$ VTAOT Drainage area $\left(m i^{2}\right)$ : -

Terrain character:

Stream character \& type: -

Streambed material:

Discharge Data (cfs):

$$
\begin{aligned}
& Q_{2.33}- \\
& Q_{50}-
\end{aligned}
$$

Record flood date $(M M / D D / Y Y)$ :

Estimated Discharge (cfs): Ice conditions (Heavy, Moderate, Light) : -

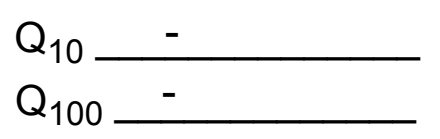

$$
\begin{aligned}
& Q_{25}- \\
& Q_{500}-
\end{aligned}
$$

Water surface elevation $(f t):-$

The stage increases to maximum highwater elevation (Rapidly, Not rapidly):

The stream response is (Flashy, Not flashy):

Describe any significant site conditions upstream or downstream that may influence the stream's stage: -

Watershed storage area (in percent): _ _ \%

The watershed storage area is: - (1-mainly at the headwaters; 2- uniformly distributed; 3-immediatly upstream oi the site)

Water Surface Elevation Estimates for Existing Structure:

\begin{tabular}{|l|l|l|l|l|l|}
\hline Peak discharge frequency & $Q_{2.33}$ & $Q_{10}$ & $Q_{25}$ & $Q_{50}$ & $Q_{100}$ \\
Water surface elevation (ft)) & - & - & - & - & - \\
Velocity (ft/sec) & - & - & - & - & - \\
\hline
\end{tabular}

Long term stream bed changes: -

Is the roadway overtopped below the $\mathrm{Q}_{100}$ ? (Yes, No, Unknown): $\mathbf{U}$ Frequency: Relief Elevation (ft): Discharge over roadway at $Q_{100}\left(f^{3} / \mathrm{sec}\right)$ :

Are there other structures nearby? (Yes, No, Unknown): $\underline{\mathbf{U}}$ Upstream distance (miles): Town: If No or Unknown, type ctrl-n os Highway No. : Structure No. : Year Built:

Clear span (ft): Clear Height $(f t)$ : Full Waterway $\left(f^{2}\right)$ : 
Downstream distance (miles): Town: Year Built:

Highway No. : Structure No. : Structure Type:

Clear span (ft): Clear Height $(f t)$ : Full Waterway $\left(f^{2}\right)$ :

Comments:

there is no undermining but there may have been settling problems that have been stabilized. Channel scour is reported to be "normal", and debris accumulation and point bars are noted as minor.

\section{USGS Watershed Data}

Watershed Hydrographic Data

Drainage area $(D A) \stackrel{51.05}{\mathbf{5 1}} \mathrm{mi}^{2}$ Lake/pond/swamp area 0.41 $\mathrm{mi}^{2}$

Watershed storage (ST) 0.8

Bridge site elevation 960 $\%$

Main channel length 12.30 $\mathrm{ft}$

Headwater elevation 3300 $\mathrm{ft}$ $10 \%$ channel length elevation $\mathbf{9 8 0}$ $\mathrm{ft} \quad 85 \%$ channel length elevation 1810 $\mathrm{ft}$

Main channel slope $(S)$

(S) 89.96 $\mathrm{ft} / \mathrm{mi}$

Watershed Precipitation Data

Average site precipitation in Average headwater precipitation in

Maximum 2yr-24hr precipitation event $(124,2)$ in

Average seasonal snowfall (Sn) $\mathrm{ft}$ 


\section{Bridge Plan Data}

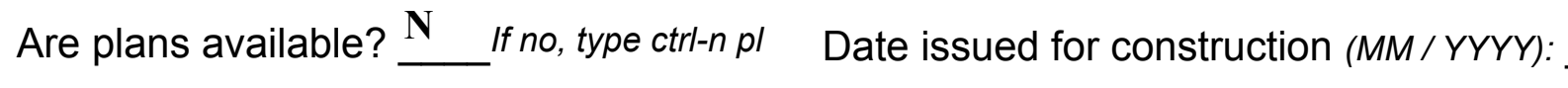

Project Number

Minimum channel bed elevation:

Low superstructure elevation: USLAB DSLAB USRAB DSRAB Benchmark location description:

NO BENCHMARK INFORMATION

Reference Point (MSL, Arbitrary, Other): Datum (NAD27, NAD83, Other):

Foundation Type: 4

If 1 : Footing Thickness

If 2: Pile Type:

If 3: Footing bottom elevation:

Is boring information available? $\mathbf{N}$

Foundation Material Type: $\mathbf{3}$

(1-Spreadfooting; 2-Pile; 3- Gravity; 4-Unknown)

Footing bottom elevation: -

Briefly describe material at foundation bottom elevation or around piles:

NO FOUNDATION MATERIAL INFORMATION 


\section{Cross-sectional Data}

Is cross-sectional data available? $\underline{\mathbf{Y}}$ If no, type ctrl-n xs

Source (FEMA, VTAOT, Other)? FEMA

Comments: This cross section is the upstream face. The low chord and bed elevations are from the cross sections done by the U.S. Department of Housing and Urban Development.

\begin{tabular}{|l|l|l|l|l|l|l|l|l|l|l|l|}
\hline Station & 192 & 193 & 193 & 193 & 202 & 209 & 218 & 227 & 236 & - & - \\
\hline Feature & LB & & & & & & & & RB & - & - \\
\hline $\begin{array}{l}\text { Low chord } \\
\text { elevation }\end{array}$ & 955.6 & 955.6 & 955.6 & 955.6 & 955.9 & 956.1 & 956.4 & 956.7 & 957.0 & - & - \\
\hline $\begin{array}{l}\text { Bed } \\
\text { elevation }\end{array}$ & 947.0 & 947.0 & 946.2 & 946.0 & 945.0 & 943.1 & 943.8 & 946.2 & 951.3 & - & - \\
\hline $\begin{array}{l}\text { Low chord } \\
\text { to bed }\end{array}$ & $\mathbf{8 . 6}$ & $\mathbf{8 . 6}$ & 9.4 & 9.6 & 10.9 & 13.0 & 12.6 & 10.5 & 5.7 & - & - \\
\hline Station & - & - & - & - & - & - & - & - & - & - & - \\
\hline Feature & - & - & - & - & - & - & - & - & - & - & - \\
\hline $\begin{array}{l}\text { Low chord } \\
\text { elevation }\end{array}$ & - & - & - & - & - & - & - & - & - & - & - \\
\hline $\begin{array}{l}\text { Bed } \\
\text { elevation }\end{array}$ & - & - & - & - & - & - & - & - & - & - & - \\
\hline $\begin{array}{l}\text { Low chord } \\
\text { to bed }\end{array}$ & - & - & - & - & - & - & - & - & - & - & - \\
\hline
\end{tabular}

Source (FEMA, VTAOT, Other)?

Comments:

\begin{tabular}{|l|l|l|l|l|l|l|l|l|l|l|l|}
\hline Station & - & - & - & - & - & - & - & - & - & - & - \\
\hline Feature & - & - & - & - & - & - & - & - & - & - & - \\
\hline $\begin{array}{l}\text { Low chord } \\
\text { elevation }\end{array}$ & - & - & - & - & - & - & - & - & - & - & - \\
\hline $\begin{array}{l}\text { Bed } \\
\text { elevation }\end{array}$ & - & - & - & - & - & - & - & - & - & - & - \\
\hline $\begin{array}{l}\text { Low chord } \\
\text { to bed }\end{array}$ & - & - & - & - & - & - & - & - & - & - & - \\
\hline Station & - & - & - & - & - & - & - & - & - & - & - \\
\hline Feature & - & - & - & - & - & - & - & - & - & - & - \\
\hline $\begin{array}{l}\text { Low chord } \\
\text { elevation }\end{array}$ & - & - & - & - & - & - & - & - & - & - & - \\
\hline $\begin{array}{l}\text { Bed } \\
\text { elevation }\end{array}$ & - & - & - & - & - & - & - & - & - & - & - \\
\hline $\begin{array}{l}\text { Low chord } \\
\text { to bed }\end{array}$ & - & - & - & - & - & - & - & - & - & - & - \\
\hline
\end{tabular}




\section{APPENDIX E: \\ LEVEL I DATA FORM}


U. S. Geological Survey

Bridge Field Data Collection and Processing Form

Qa/Qc Check by: $\underline{\mathbf{R B}}$ Date: $2 / 29 / 96$

\section{Structure Number}

BURKTH00560020

Computerized by: $\underline{\mathbf{R B}}$ Date: $2 / 29 / 96$

Reviewd by: MS Date: $\underline{\mathbf{5} / \mathbf{2 0} / \mathbf{9 8}}$

\section{A. General Location Descriptive}

1. Data collected by (First Initial, Full last name) $\mathbf{T}$. SEVERANCE

Date $(M M / D D / Y Y) \underline{08} / \underline{15} / 1995$

2. Highway District Number $\mathbf{0 7}$

County CALEDONIA (005)

Waterway $(l$ - 6) EAST BR. PASSUMPSIC RIVER

Route Number TH056
Mile marker 0000

Town BURKE (10450)

Road Name -

Hydrologic Unit Code: $\mathbf{0 1 0 8 0 1 0 2}$

3. Descriptive comments:

The structure is located 0.75 miles south of Hartwellville off of VT 114, 100 feet east of the intersection of VT 114 and TH056. There is a USGS gaging station just DS on the right bank. The structure is located in Caledonia County, 0.3 miles from the Caledonia/Essex County border.

\section{B. Bridge Deck Observations}
4. Surface cover... LBUS 6
RBUS 6
LBDS 6
RBDS 6
Overall 6

(2b us,ds,lb,rb: 1- Urban; 2- Suburban; 3- Row crops; 4- Pasture; 5- Shrub- and brushland; 6- Forest; 7- Wetland)
5. Ambient water surface... US $\underline{2}$
UB 1
DS $\underline{2}$
(1- pool; 2- riffle)

6. Bridge structure type 1 (1- single span; 2- multiple span; 3- single arch; 4- multiple arch; 5-cylindrical culvert; 6- box culvert; or 7- other)
7. Bridge length 46
(feet)
Span length 44
(feet)
Bridge width 13.6 (feet)

\section{Road approach to bridge:}
8. LB 1
RB 2
( 0 even, 1- lower, 2- higher)
9. LB_2
RB $\underline{2}$
(1-Paved, 2- Not paved)

10. Embankment slope (run / rise in feet / foot)

$$
\text { US left }
$$

0.0:1

US right

0.0:1

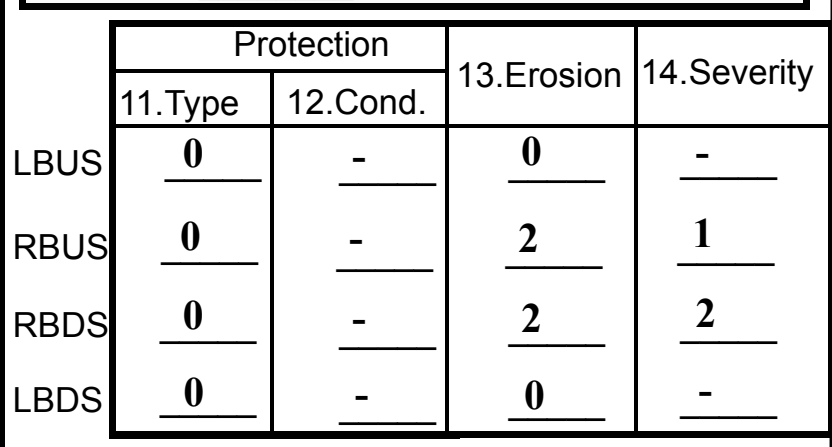

Bank protection types: 0- none; 1- $<12$ inches;

2- < 36 inches; 3- < 48 inches;

4- < 60 inches; 5- wall / artificial levee

Bank protection conditions: 1- good; 2- slumped;

3- eroded; 4- failed

Erosion: 0 - none; 1- channel erosion; 2-

road wash; 3- both; 4- other

Erosion Severity: 0 - none; 1- slight; 2- moderate;

\section{Channel approach to bridge (BF):}

15. Angle of approach: 60

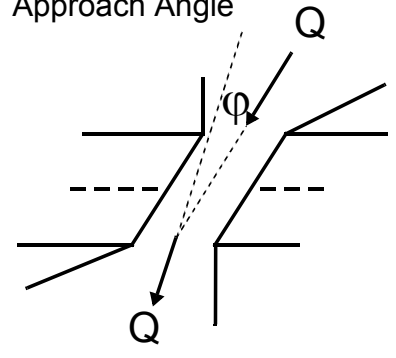

17. Channel impact zone 1:

Where? RB (LB, RB)

Range? 100 feet $\underline{\mathbf{U S}}$

Channel impact zone 2:

Where? $(L B, R B)$

Range? - $\quad$ feet (US, UB, DS) to feet -

Impact Severity: 0- none to very slight; 1-Slight; 2- Moderate; 3- Severe
16. Bridge skew: $\mathbf{3 0}$

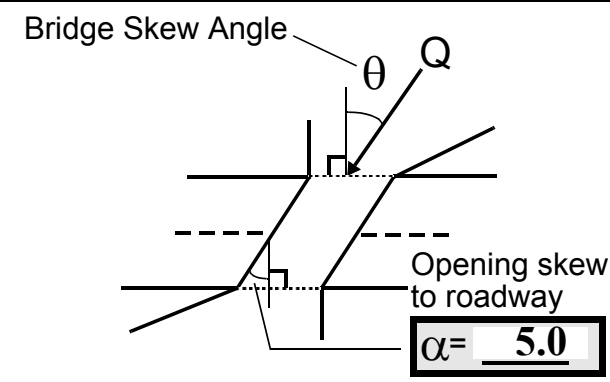

Exist? $\mathbf{Y}(Y$ or $N)$

Severity 2

(US, UB, DS) to $\underline{\mathbf{5 0}}$ feet $\underline{\mathbf{D S}}$

Exist? $\mathbf{N}(Y$ or $N)$

Severity -

o roadway 
18. Bridge Type: 1a

1a- Vertical abutments with wingwalls

$1 \mathrm{~b}$ - Vertical abutments without wingwalls

2- Vertical abutments and wingwalls, sloping embankment Wingwalls parallel to abut. face

3- Spill through abutments

4- Sloping embankment, vertical wingwalls and abutments

Wingwall angle less than $90^{\circ}$.

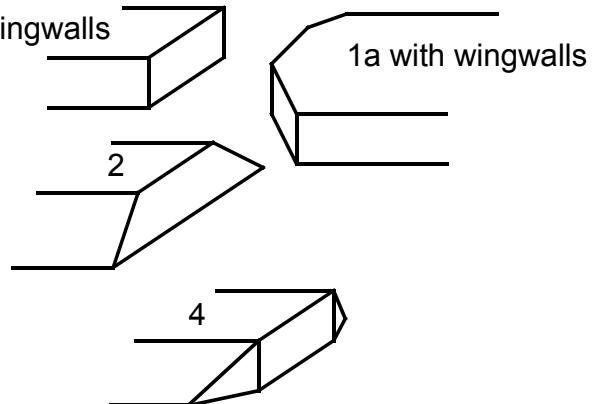

19. Bridge Deck Comments (surface cover variations, measured bridge and span lengths, bridge type variations,

approach overflow width, etc.)

4. The surface cover is predominantly forest except for the road, VT 114, to the west, and the US and DS sections of lawn on the left bank. The immediate banks are wooded with shrubs. The road on the left bank will overflow well before the bridge will overflow.

7. The values are from the VTAOT files. Measured bridge length $=45.2$ feet, span length $=44.0$ feet, and bridge width $=13.0$ feet.

\section{Upstream Channel Assessment}

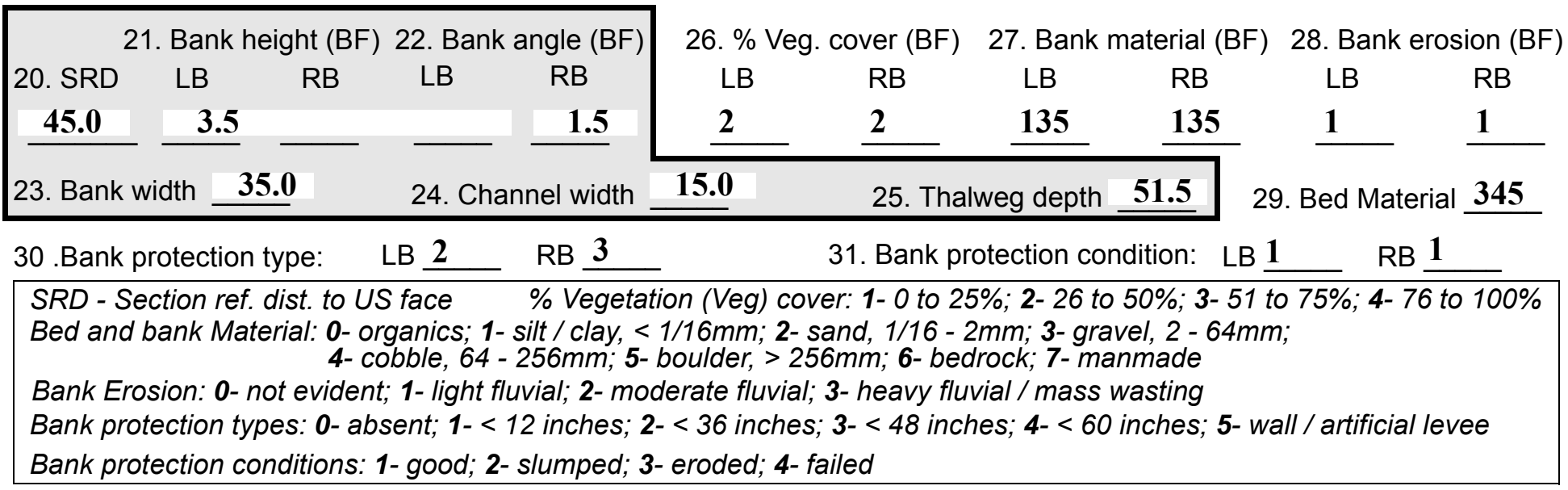

32. Comments (bank material variation, minor inflows, protection extent, etc.):

27. The bank material is predominantly silts and clays with some gravel and boulders. The right bank is lined with boulders (cut granite slabs) over the range of channel impact zone 1.

29. Beyond two bridge lengths the bed is made up of more gravel and cobble. Within two bridge lengths, there are a significant number of boulders.

The US thalweg depth is 1 foot, average thalweg depth for the stream upstream and downstream of the bridge is 1.5 feet. 
36. Point bar extent: $\mathbf{8 0}$ feet $\underline{\text { US }}$

(US, UB) to 110 feet $\underline{\mathbf{U S}}$

(US, UB, DS) positioned $\underline{\mathbf{0}}$

\%LB to 20 $\%$ RB

37. Material: $\mathbf{3}$

38. Point or side bar comments (Circle Point or Side; Note additional bars, material variation, status, etc.):

At lower flows this side bar would be more visible and flow would be positioned just right of the center of the channel.

39. Is a cut-bank present? $\mathbf{N}$ ( $Y$ or if $N$ type ctrl-n cb) 40. Where? - $\quad$ (LB or RB)

41. Mid-bank distance: -

42. Cut bank extent: feet (US, UB) to feet (US, UB, DS)

43. Bank damage: = (1- eroded and/or creep; 2- slip failure; 3- block failure)

44. Cut bank comments (eg. additional cut banks, protection condition, etc.):

NO CUT BANKS

45. Is channel scour present? $\mathbf{Y}$ ( $Y$ or if $N$ type ctrl-n cs)

47. Scour dimensions: Length $\underline{40}$ Width 6 Depth : 1.5 46. Mid-scour distance: $\mathbf{3 5}$ Position $\underline{40} \%$ LB to $\underline{65}$ \%RB

48. Scour comments (eg. additional scour areas, local scouring process, etc.):

This scour continues under the bridge. There are a lot of boulders scattered in the hole along its length.

49. Are there major confluences? $\mathbf{N}$

51. Confluence 1: Distance Confluence 2: Distance 52. Enters on Enters on 54. Confluence comments (eg. confluence name):

NO MAJOR CONFLUENCES
50. How many? -

53. Type(1- perennial; 2- ephemeral)

Type (1-perennial; 2- ephemeral) (1-perennial, 2-ephemeral) ( $(L B$ or $R B)$ (LB or $R B)$ 
65. Debris and Ice Is there debris accumulation?

67. Debris Potential $\underline{3}$ (1- Low; 2- Moderate; 3- High)

69. Is there evidence of ice build-up? 2

70. Debris and Ice Comments:

1

Both the left and right banks US are gradual slopes. The right bank becomes steeper approaching VT 114. At bank full there is evidence of some capture amongst shrubs and saplings and there is a section of flattened long grass. On the US left bank, there is a 16-inch diameter tree with obvious ice damage.

\begin{tabular}{|l|c|c|c|c|c|c|c|c|}
\hline Abutments & $\begin{array}{c}\text { 71. Attack } \\
\angle \text { (BF) }\end{array}$ & $\begin{array}{c}\text { 72. Slope } \angle \\
\text { (Qmax) }\end{array}$ & $\begin{array}{c}\text { 73. Toe } \\
\text { loc. (BF) }\end{array}$ & $\begin{array}{c}\text { 74. Scour } \\
\text { Condition }\end{array}$ & $\begin{array}{c}\text { 75. Scour } \\
\text { depth }\end{array}$ & $\begin{array}{c}\text { 76. Exposure } \\
\text { depth }\end{array}$ & 77. Material & 78. Length \\
\hline LABUT & & - & $\mathbf{8 5}$ & $\mathbf{2}$ & $\mathbf{3}$ & $\mathbf{1 . 0}$ & $\mathbf{2 . 5}$ & $\mathbf{9 0 . 0}$ \\
\hline RABUT & $\mathbf{2}$ & $\mathbf{3 0}$ & $\mathbf{9 0}$ & & & $\mathbf{2}$ & $\mathbf{0}$ & $\mathbf{4 0 . 5}$ \\
\hline
\end{tabular}

Pushed: $L B$ or RB

Toe Location (Loc.): 0- even, 1- set back, 2- protrudes

Scour cond.: 0- not evident; 1- evident (comment); 2- footing exposed; 3-undermined footing; 4- piling exposed; 5- settled; 6- failed

Materials: 1- Concrete; 2- Stone masonry or drywall; 3- steel or metal; 4- wood

79. Abutment comments (eg. undermined penetration, unusual scour processes, debris, etc.):

$-$

1

74. The US left abutment footing is undermined with penetration of 2 feet with a range pole. This condition continues from the US bridge face to six feet downstream. From that point on, the footing is exposed but not undermined.

75,76 Because of the boulders piled in front of the footing, the exposure depth approaches 4 feet at 2 feet away from the abutment into the channel. This condition extends from the US bridge face for 4 feet DS under the bridge. Scour depth is 1.5 feet at this point. The right abutment footing is beneath 0.5 foot of sand and silt at the US end and 1 foot of sand and silt at the DS end. There is air space between the stone protection on the

80. Wingwalls:

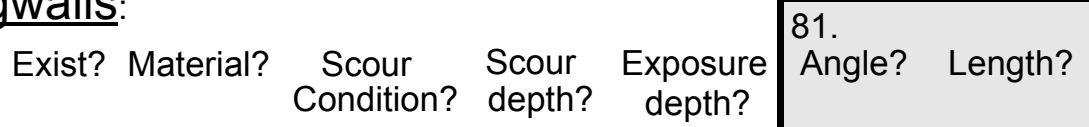

USLWW: bank

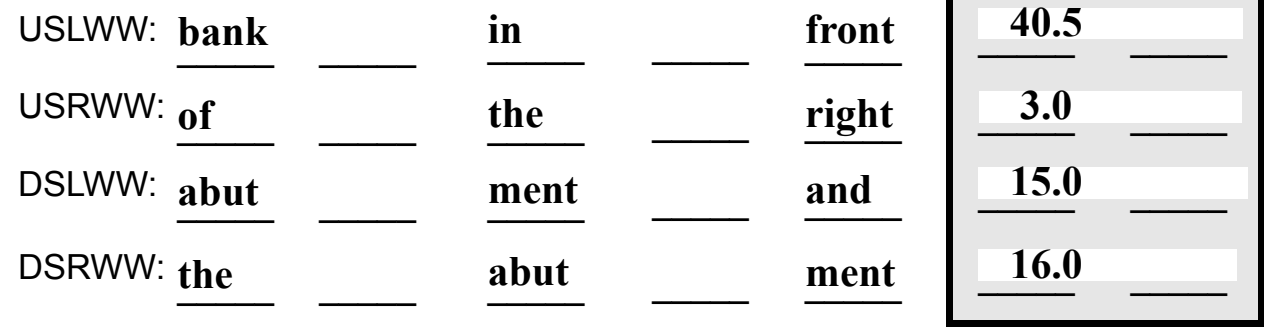

Wingwall materials: 1- Concrete; 2- Stone masonry or drywall; 3- steel or metal; 4- wood

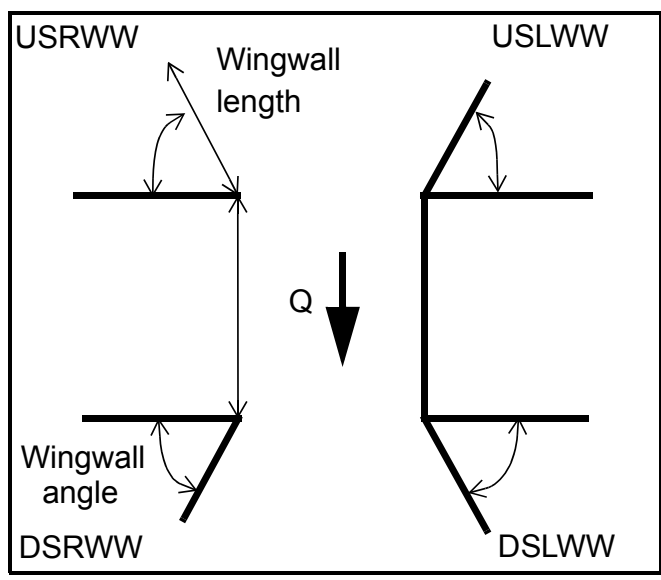

82. Bank / Bridge Protection:

\begin{tabular}{|l|l|l|l|l|l|l|l|l|}
\hline Location & USLWW & USRWW & LABUT & RABUT & LB & RB & DSLWW & DSRWW \\
\hline Type & itsel & thal & h is & aver & weg & $\mathbf{1 . 5}$ & ing & s is \\
\hline Condition & f. & weg & $\mathbf{3}$ & age & dept & feet. & thic & $\mathbf{1 . 7 5}$ \\
\hline Extent & The & dept & feet, & thal & h is & Foot & knes & feet. \\
\hline
\end{tabular}

Bank / Bridge protection types: 0- absent; 1- < 12 inches; 2- < 36 inches; 3- < 48 inches; 4- < 60 inches; 
83. Wingwall and protection comments (eg. undermined penetration, unusual scour processes, etc.):

Y
2
3
1.0
2.5
$Y$
1
0
-
-
$Y$

\section{Piers:}

84. Are there piers? 2 (Y or if $N$ type ctrl-n pr)

\begin{tabular}{|l|l|l|l|l|l|l|l|}
\hline \multirow{2}{*}{$\begin{array}{l}85 . \\
\text { Pier no. }\end{array}$} & \multicolumn{3}{|c|}{ width (w) feet } & \multicolumn{5}{c|}{ elevation (e) feet } \\
\cline { 2 - 8 } & w1 & w2 & w3 & e@w1 & e@w2 & e@w3 \\
\hline Pier 1 & & & & $\mathbf{3 5 . 0}$ & $\mathbf{1 7 . 5}$ & $\mathbf{4 0 . 0}$ \\
\hline Pier 2 & & & $\mathbf{9 . 0}$ & $\mathbf{1 1 . 5}$ & $\mathbf{3 0 . 0}$ & $\mathbf{3 0 . 0}$ \\
\hline Pier 3 & & - & - & $\mathbf{1 0 . 5}$ & - & - & \\
\hline Pier 4 & - & - & - & - & - & - & w1 \\
\hline
\end{tabular}

\begin{tabular}{|l|l|l|l|l|}
\hline Level 1 Pier Descr. & \multicolumn{1}{|c|}{1} & \multicolumn{1}{|c|}{2} & 3 & \multicolumn{1}{|c|}{4} \\
\hline 86. Location (BF) & $\mathbf{0}$ & $\mathbf{1}$ & - & condi- \\
\hline 87. Type & - & $\mathbf{1}$ & - & tion \\
\hline 88. Material & - & $\mathbf{0}$ & $\mathbf{2}$ & for \\
\hline 89. Shape & $\mathbf{Y}$ & - & $\mathbf{3}$ & the \\
\hline 90. Inclined? & $\mathbf{1}$ & - & $\mathbf{2}$ & US \\
\hline 91. Attack $\angle$ (BF) & $\mathbf{0}$ & $\mathbf{3}$ & $\mathbf{3}$ & left \\
\hline 92. Pushed & - & $\mathbf{1}$ & $\mathbf{1}$ & wing \\
\hline 93. Length (feet) & - & - & - & - \\
\hline 94. \# of piles & - & $\mathbf{1}$ & $\mathbf{1}$ & wall \\
\hline 95. Cross-members & $\mathbf{2}$ & $\mathbf{0}$ & $\mathbf{8 0 .}$ & is the \\
\hline 96. Scour Condition & $\mathbf{3}$ & - & The & same \\
\hline 97. Scour depth & $\mathbf{1}$ & - & scou & as \\
\hline 98. Exposure depth & $\mathbf{3}$ & $\mathbf{0}$ & r & for \\
\hline
\end{tabular}

LFP, LTB, LB, MCL, MCM, MCR, RB, RTB, RFP

1- Solid pier, 2- column, 3- bent

1- Wood; 2- concrete; 3- metal; 4- stone

1- Round; 2- Square; 3- Pointed

Y-yes; $N$ - no

$L B$ or $R B$

0- none; 1- laterals; 2- diagonals; 3- both

0- not evident; 1- evident (comment);

2- footing exposed; 3- piling exposed;

4- undermined footing; 5- settled; 6-failed 
99. Pier comments (eg. undermined penetration, protection and protection extent, unusual scour processes, etc.):

the left abutment. It is possible to penetrate approximately 4 inches. Note that the footing is made up of granite slabs which are not cut perfectly square, this makes undermining measurement values more pronounced.

82. The protection described for the US and DS left wingwalls consists of small boulders placed at the base of the wingwalls.

Scour holes beneath the bridge are located along the right side of the channel close to the abutment and at the US end of the left abutment-intersection with the wingwall. The bottom of the scour hole located by the upstream section of the left abutment is sandy.

100.

\section{E. Downstream Channel Assessment}

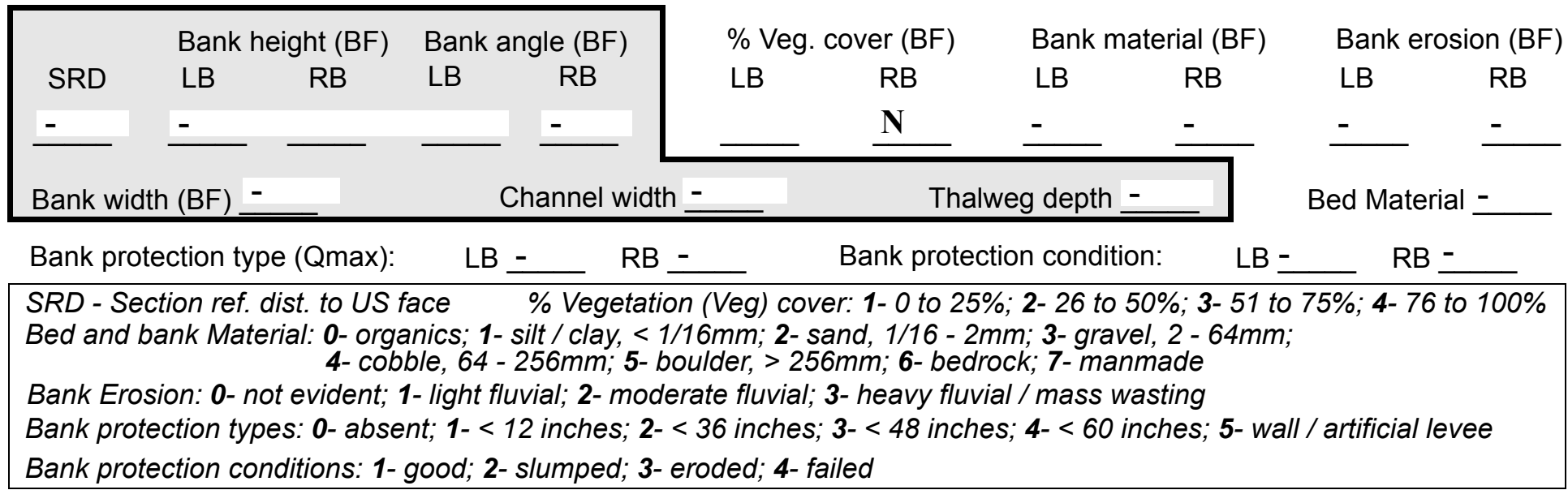

Comments (eg. bank material variation, minor inflows, protection extent, etc.):

$-$

$-$

$-$

$-$

$-$

$-$

101. Is a drop structure present? _ ( $Y$ or $N$, if $N$ type ctrl-n ds) 102. Distance: ___ feet
103. Drop: - feet
104. Structure material: -
(1- steel sheet pile; 2- wood pile; 3- concrete; 4- other)

105. Drop structure comments (eg. downstream scour depth): 
106. Point/Side bar present? (Y or $N$. if $N$ type ctrl-n pb)Mid-bar distance:

Mid-bar width: -

Point bar extent: feet -

(US, UB, DS) to feet (US, UB, DS) positioned $\%$ LB to $\% \mathrm{RB}$ Material:

Point or side bar comments (Circle Point or Side; note additional bars, material variation, status, etc.):

Is a cut-bank present? ___ (Y or if $N$ type ctrl-n cb) Where? - _ (LB or RB) Mid-bank distance: NO Cut bank extent: $\underline{\text { PIE feet }}$ RS (US, UB, DS) to feet (US, UB, DS)

Bank damage: (1- eroded and/or creep; 2- slip failure; 3- block failure)

Cut bank comments (eg. additional cut banks, protection condition, etc.):

Is channel scour present? Scour dimensions: Length $\mathbf{2}$ Width 4 (Y or if $N$ type ctrl-n cs)

Mid-scour distance:

Scour comments (eg. additional scour areas, local scouring process, etc.): 0 345

0 123

Are there major confluences? Confluence 1: Distance The Confluence 2: Distance $\mathbf{k}$ has Enters on left (LB or RB) Positioned $\underline{\mathbf{4 5}} \%$ LB to 1 \%RB Confluence comments (eg. confluence name):

$20 \mathrm{ft}$ of trees between the stream and lawn. The right bank is thickly wooded for 40-60 feet from the right bank up to VT 114. The left overbank is fairly flat and then slopes up slightly to a house and TH056. This ter-

\section{F. Geomorphic Channel Assessment}

$\begin{array}{ll}\text { 107. Stage of reach evolution rai } & \text { 1- Constructed } \\ \text { 2-Stable } & \text { 3-Aggraded } \\ \text { 4- Degraded } & \text { 5- Laterally unstable } \\ & \mathbf{6} \text { - Vertically and laterally unstable }\end{array}$


108. Evolution comments (Channel evolution not considering bridge effects; See HEC-20, Figure 1 for geomorphic descriptors):

n description is similar for the left overbank US.

On the right bank a USGS gage house is within one bridge length of the DS face of the bridge.

Many cobbles and boulders are on the DS right bank from the bridge to beyond 200 feet downstream. At 200 feet DS the channel bends to the right. The left side of the channel cross section is predominantly cobbles and gravel. The right side has larger cobbles to small boulders.

The thalweg depth is 2 feet. 


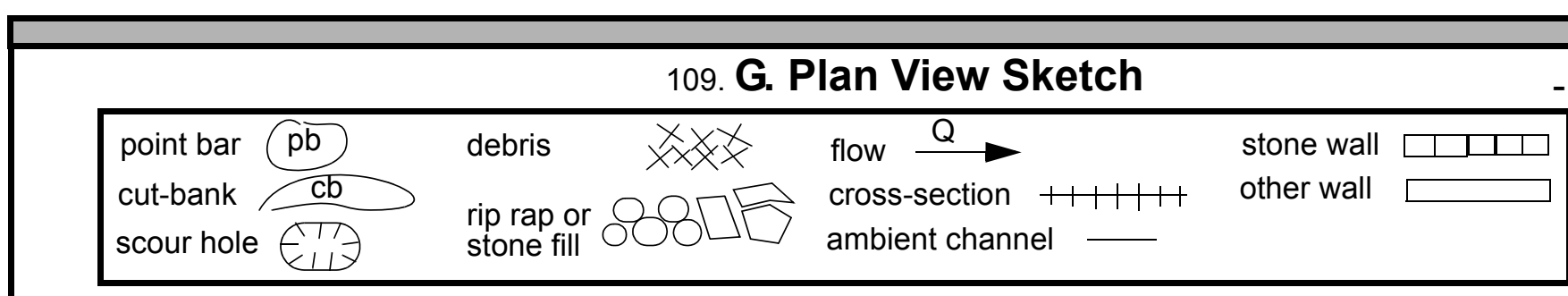


APPENDIX F:

SCOUR COMPUTATIONS 
SCOUR COMPUTATIONS

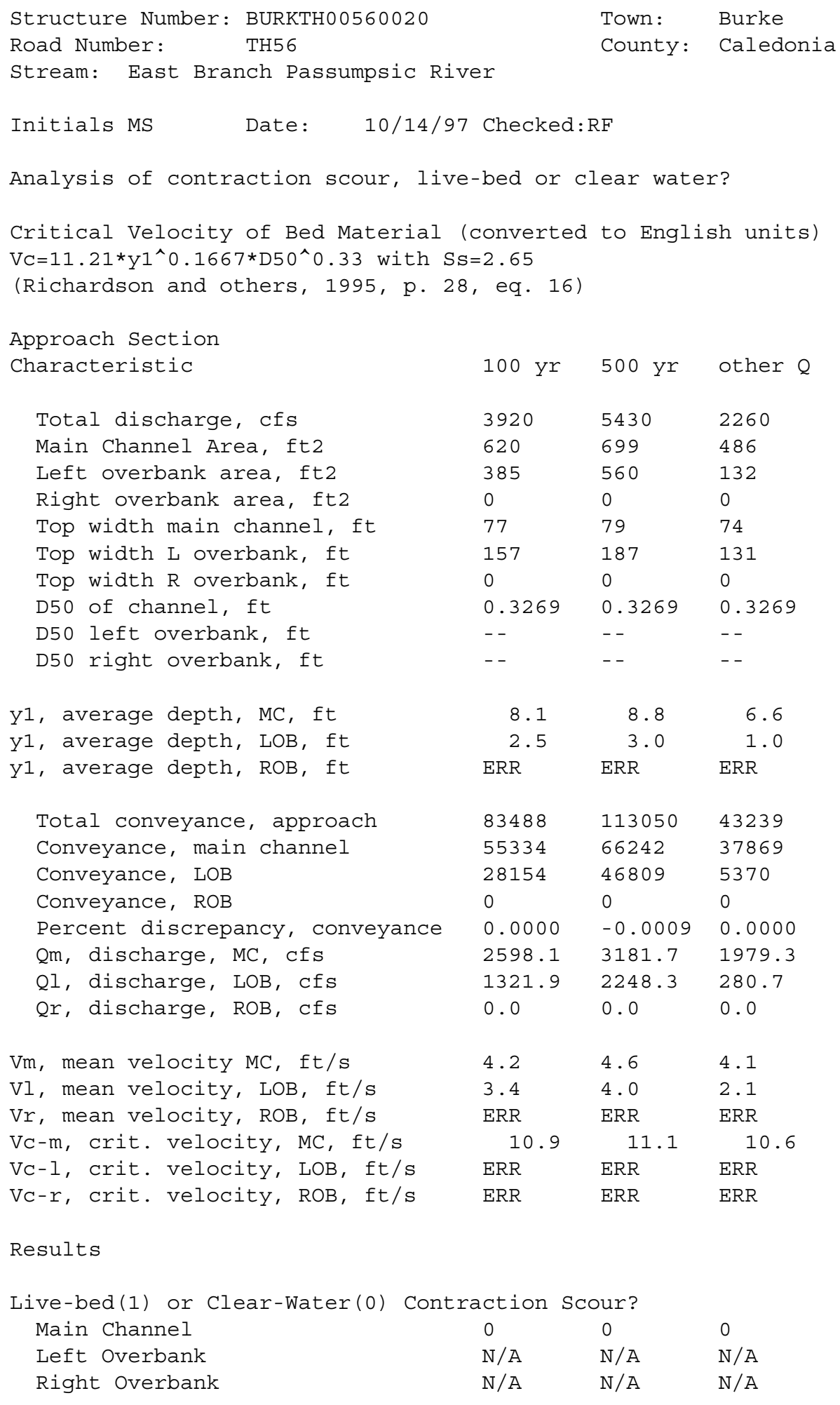




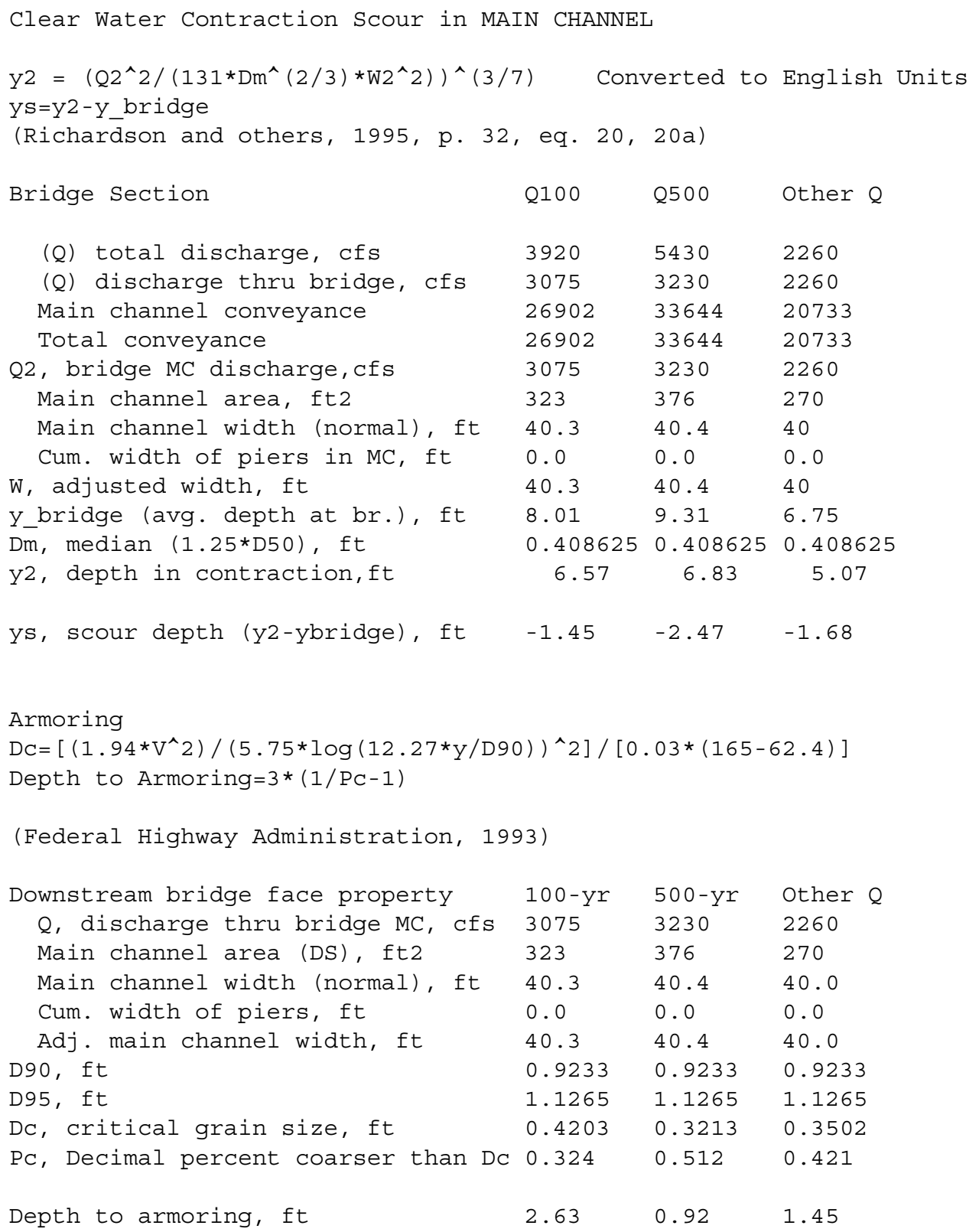




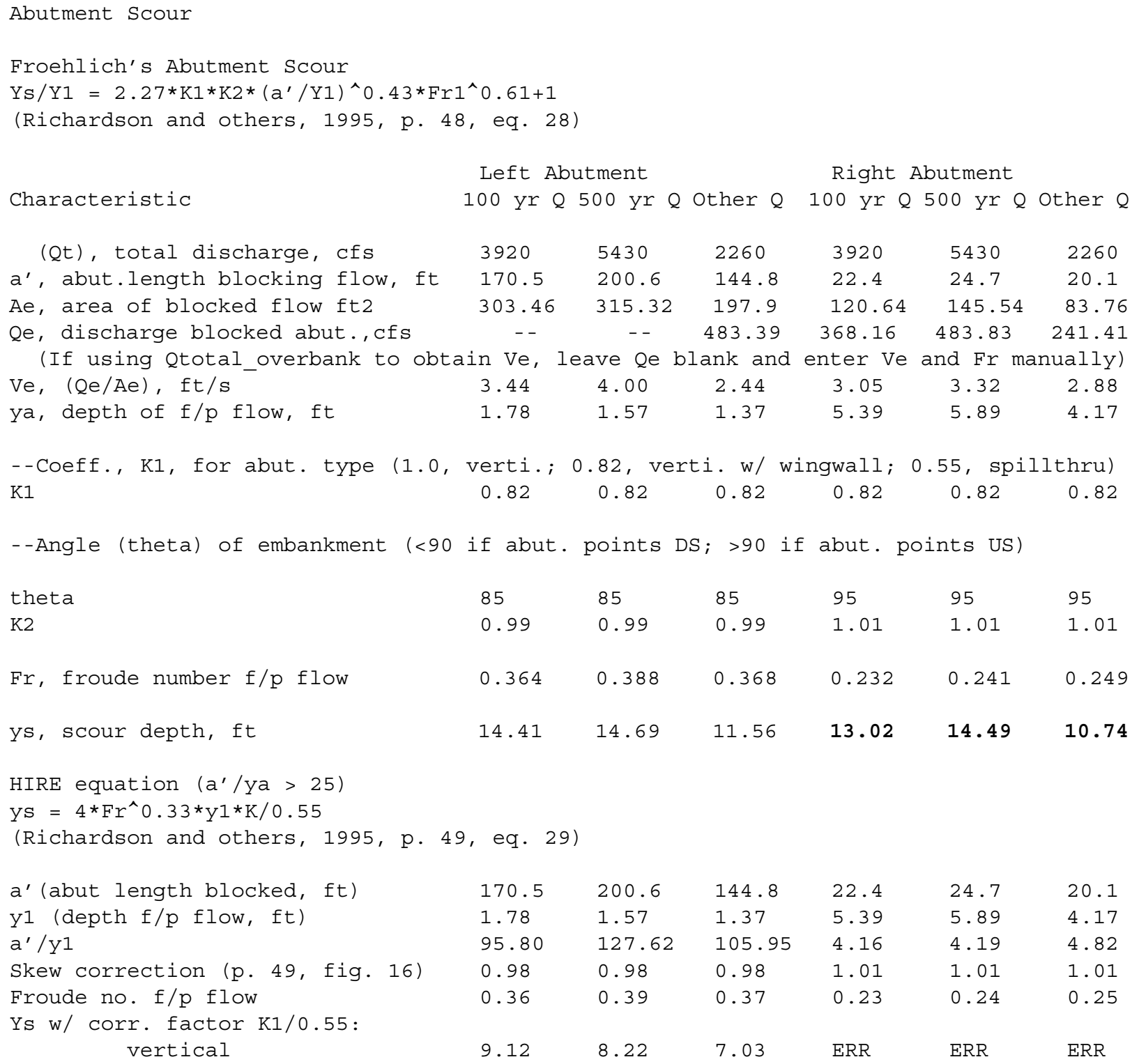




$\begin{array}{lllllll}\text { vertical w/ wW's } & \mathbf{7 . 4 7} & \mathbf{6 . 7 4} & \mathbf{5 . 7 6} & \text { ERR } & \text { ERR } & \text { ERR } \\ \text { spill-through } & 5.01 & 4.52 & 3.86 & \text { ERR } & \text { ERR } & \text { ERR }\end{array}$

\begin{tabular}{|c|c|c|c|c|c|}
\hline \multicolumn{6}{|c|}{$\begin{array}{l}\text { Isbash Relationship } \\
\mathrm{D} 50=\mathrm{Y}^{\star} \mathrm{K} * \mathrm{Fr} r^{\wedge} 2 /(\mathrm{Ss}-1) \text { and } \mathrm{D} 50=\mathrm{Y}^{*} \mathrm{~K} *\left(\mathrm{Fr} \mathrm{r}^{\wedge}\right)^{\wedge} 0.14 /(\mathrm{Ss}-1) \\
(\text { Richardson and others, 1995, p112, eq. 81,82) }\end{array}$} \\
\hline Characteristic & Q500 & Other $Q$ & Q100 & Q500 & Other $Q$ \\
\hline Fr, Froude Number & 0.55 & 0.58 & 0.63 & 0.55 & 0.58 \\
\hline$y$, depth of flow in bridge, ft & 9.31 & 6.75 & 8.01 & 9.31 & 6.75 \\
\hline $\begin{array}{l}\text { Median Stone Diameter for riprap at: left } \\
\text { Fr }<=0.8 \text { (vertical abut.) }\end{array}$ & $\begin{array}{c}\text { butment } \\
1.74\end{array}$ & 1.40 & $\begin{array}{l}\text { right } \\
1.97\end{array}$ & $\begin{array}{r}\text { abutment } \\
1.74\end{array}$ & ft 1.40 \\
\hline
\end{tabular}

